\title{
HEALTH CARE REFORM: CAN TORT LAW MEET THE CHALLENGE?'
}

\section{TIMOTHY A. CAULFIELD}

This article discusses the legal implications of the current trend toward cost containment and restructuring in the Canadian health care system. It examines the remedies available to patients who have been negatively affected by cost containment decisions.

Because physicians have ultimate control over the allocation of medical resources, doctors will likely be the primary defendants in malpractice litigation when expensive treatment or medical procedures are withheld from the patient for cost containment reasons. The various factors which are relevant to the success of these types of actions are examined, including a consideration of concepts such as the "locality rule" and "medical custom". The article then discusses whether hospitals and other third party decision makers are more appropriate defendants in cost containment litigation, and whether they could be found liable for their decisions. The author concludes that tort law may be, at least in the short term, a viable mechanism for patients who wish to obtain compensation for injuries that result from health care which is substandard due to cost containment strategies.
L'auteur étudie les incidences juridiques de la tendance actuelle vers la compression des coûts et la restructuration du système de santé canadien. Il examine les recours offerts aux victimes des mesures d'austérité.

Parce que les médecins ont le contrôle ultime des ressources medicales (quand ils refusent certains traitements ou interventions coûteuses pour des raisons pécuniaires), ils seront sans doute les premiers incriminés dans les poursuites invoquant la faute médicale. Le succès de ces poursuites dépend d'un certain nombre de facteurs - la règle dite du milieu et l'usage en matière médicale notamment. L'auteur examine s'il serait plus approprié de poursuivre les hopitaux et les autres décideurs, et si leur responsabilité pourrait être engagée. Il conclut que le droit de la responsabilité délictuelle pourrait, tout du moins à court terme, offrir un mécanisme efficace aux patients qui revendiquent l'indemnisation de préjudices causés par des soins médiocres, résultant de mesures de limitation des coùts.

\section{TABLE OF CONTENTS}

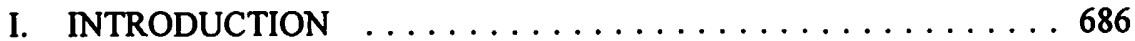

II. PHYSICIANS AS TARGETS OF COST

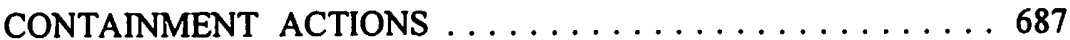

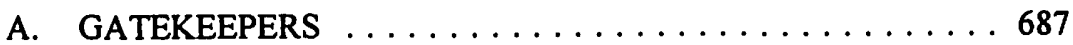

B. THIRD PARTY INFLUENCE ON THE

PRACTICE OF MEDICINE . . . . . . . . . . . . 688

C. EROSION OF THE PATIENT'S TRUST $\ldots \ldots \ldots \ldots \ldots 691$

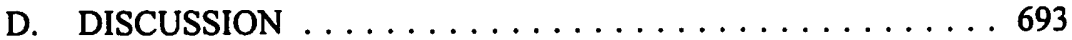

III. WILL LIABILITY BE IMPOSED ON PHYSICIANS? . . . . . 694

A. THE REAL AND PERCEIVED LOWERING

OF THE QUALITY OF CARE . . . . . . . . . . . 694

B.Sc., LL.B., LL.M., Research Director, Health Law Institute, University of Alberta. I would like to thank Robert Elgie, Patty James, Bartha Maria Knoppers and Gerald Robertson for their helpful comments. A version of this article was commissioned by the Canadian Bar Association Task Force on Health Care, April 1994.

1 Portions of this article are taken from T. Caulfield, "The Last Straw: The Impact of Cost Containment in Health Care on Medical Malpractice Law" (LL.M. Thesis, Dalhousie University, 1993). 

B. SUING PHYSICIANS FOR
SUBSTANDARD HEALTH CARE . . . . . . . . . . 697
C. LEGAL PRINCIPLES WHICH MAY ACCOMMODATE
COST CONTAINMENT IN HEALTH CARE . . . . . 703

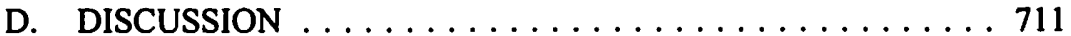

IV. THIRD PARTY LIABILITY - HOSPITALS AND

THIRD PARTY DECISION-MAKERS $\ldots \ldots \ldots \ldots \ldots \ldots 711$

A. HOSPITAL LIABILITY $\ldots \ldots \ldots \ldots \ldots \ldots \ldots \ldots \ldots \ldots$

B. LIABILITY OF THIRD PARTY

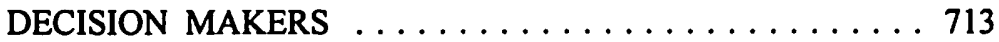

V. NEW AREAS OF LIABILITY $\ldots \ldots \ldots \ldots \ldots \ldots \ldots \ldots 717$

A. THE CONCEPT OF

B. ACTIONS BASED ON A BREACH OF

THE FIDUCIARY DUTY $\ldots \ldots \ldots \ldots \ldots \ldots \ldots$

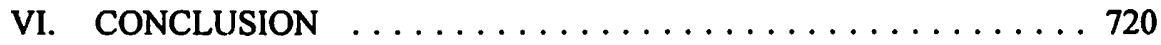

\section{INTRODUCTION}

While it once seemed little more than an idle threat, rationing in health care has emerged as a realistic prospect. At the very least, the Canadian health care system is headed toward an era of aggressive cost containment and drastic restructuring. How will Canadian patients protect their interests in the face of these radical changes? What legal mechanisms are at their disposal? This article will analyze the use of tort law as one such mechanism.

Because of the dominant role physicians play in the Canadian health care system, an understanding of how cost containment will affect the medical profession is essential to the analysis of this issue. Physicians are the gatekeepers of our society's medical resources, they have the ultimate control of patient care, and they are the primary defendants in malpractice litigation. Therefore, if physicians can successfully avoid, or defend against, cost containment malpractice actions, the effectiveness of tort law as a mechanism for the protection of patients' access to high quality health care will be greatly diminished.

The first section of this article is a discussion of why physicians will likely be the primary targets of malpractice actions which arise as a result of cost containment in health care. This will be followed by an examination of the various factors which are relevant to the success of these types of actions. This will include a consideration of concepts such as the "locality rule" and "medical custom". The next section of the article will discuss whether hospitals and other third party decision makers could be found liable for their cost containment decisions. Finally, this article will review two novel areas of liability which may arise as a result of cost containment policies. 


\section{PHYSICIANS AS TARGETS OF COST CONTAINMENT ACTIONS}

Below is a discussion of a number of the more salient reasons why physicians find themselves at the centre of the cost containment controversy.

\section{A. GATEKEEPERS}

Regardless of where a cost containment decision originates, it is the physician who will ultimately implement the policy at the "micro" level. One American commentator stated:

[T] he process of rationing is conducted on the micro level, usually by physicians acting as agents of the medical specialty, payer, hospital or other entity whose policies they have agreed to follow (or have been forced to follow). ${ }^{2}$

In many respects then, physicians act as the gatekeepers to society's medical resources. ${ }^{3}$ Their clinical discretion leave them with the bottom line decision making power as the "micro" allocators. ${ }^{4}$ They control spending by determining what will be done for each patient and, therefore, cost containment cannot be implemented without

2 E. Friedman, "Freedom, Fault and Default" (1992) 14 Health Mgmt. Q. 10 at 11.

3 See R. Lee \& F. Miller, "The Doctor's Changing Role in Allocating U.S. and British Medical Services" (1990) $18 \mathrm{~L}$. Med. \& Health Care 69 at 74, for a discussion of the physician's role in the cost containment context; and R. Lee, "Legal Control of Health Care Allocation" (1986) in Medicine, Ethics and Law (Great Britain: Association for Legal and Social Philosophy, 1986) [hereinafter "Legal Control"], for a discussion of the physicians role in Great Britain. See also M. Rachlis \& C. Kushner, Second Opinion: What's Wrong with Canada's Health-Care System and How to Fix It. (Toronto: Collins, 1989) at 35, for a comment on the Canadian situation.

It is interesting to note that while physicians are the ultimate allocators of medical resources, they apparently do not do the job very well. Given the importance and value of medical resources, one would expect a great degree of scrutiny. In fact, there is a huge variation among practices and many ineffective therapies are still in use. See for example G. Gibson, "Doctors must choose the way to go" The [Toronto] Globe and Mail (18 June 1993) A19; and E. Ginzberg, "The Limitations of Health Reform Revisited" (1991) 3 Stanford L. \& Pol. Rev. 195 at 199. Also see C. Grogan, "Deciding on Access and Levels of Care: A Comparison of Canada, Britain, Germany and the United States" (1992) 17 J. Health Pol. 213 at 225-29, where the variation in the use of therapies between countries is noted. This issue is also noted by G. Agich, "Rationing and Professional Autonomy" (1990) $18 \mathrm{~L}$. Med. \& Health Care 77 at 82; and "Legal Control", ibid. at 96. To alleviate this problem many commentators have advocated the use of a greater number of outcome studies, see J. Wennberg, "Outcomes Research, Cost Containment and the Fear of Health Care Rationing" (1990) 323 New Eng. J. Med. 1202; A. Garber \& V. Fuchs, "The Expanding Role of Technological Assessment in Health Care" (1991) 3 Stanford L. \& Pol. Rev. 203; C. Harstall, "Health Technology Assessment: Rising to new heights" (1994) 1:9 Healthcare Adv. 26; EvidenceBased Care Resource Group, "Evidence-based care: 1. Setting priorities; How important is this problem?" (1994) 150 CMAJ 1249; and A Better Way: A Plan for Securing Alberla's Future (Government of Alberta, 1994). Finally, see The Royal Commission on New Reproductive Technologies, Proceed with Care (Final Report of the Royal Commission on New Reproductive Technologies, 1993) at 70, where the authors report as follows: "The evidence before the Commission suggests that a significant proportion of medical care is ineffective, inefficient, or unevaluated." 
their involvement and cooperation. ${ }^{5}$ However, while physicians have the final say in how resources are to be rationed, they may still feel pressure to do so in a manner which is not in accordance with their clinical judgment, beliefs, or usual mode of practice. ${ }^{6}$ It is this change in physicians' practice which is likely to result from cost containment initiatives and which patients may wish to monitor through the application of the tort system.

\section{B. THIRD PARTY INFLUENCE ON THE PRACTICE OF MEDICINE}

In general, Canadian physicians experience cost containment "influence" from two primary sources: governments and hospitals. These entities are often respectively called the "macro" and "meso" resource allocation decision makers."

In the past, government policies have affected physicians primarily through such activities as the negotiation of fee schedules; ${ }^{8}$ however, to date there has been minimal government limitation, or utilization control, on the treatments covered by health

See Harvard, "Rethinking Medical Malpractice Law in Light of Medicare Cost-Cutting" (1985) 98 Harvard L. Rev. 1004 at 1014-15, where the authors note that in the United States physicians control 60-75 percent of the health care expenses. Therefore, hospitals try to change physicians' behaviour through a variety of strategies such as education, peer pressure, a threatened reduction in privileges and utilization guidelines. See also E. Morreim, "Cost Containment and the Standard of Medical Care" (1987) 75 Calif. L. Rev. 1719 at 1723-24 [hereinafter "Cost Containment"] who estimates that physicians control $60-80$ percent of resources.

6 See J. Williams \& E. Beresford, "Physicians, Ethics and the Allocation of Health Care Resources" (1991) 24 Annals RCPSC 305, for a review of a study indicating that rationing of medical resources already affects practice patterns. See E. Godley, "MDs should assume more responsibility for managing health care, Royal College audience told" (1994) 150 CMAJ 76 at 76 who notes increased payor (i.e. government) involvement. See also M. Barer, "Controlling Medical Care Costs in Canada" (1991) 265 JAMA 2393 at 2394; and L. Sederer, "Judicial and Legislative Responses to Cost Containment" (1992) 149 Am. J. Psych. 1157 at 1160-61, who notes that "fiscal and political pressures...have intensified." Further, he believes that physicians should not be in a situation where they have an economic incentive not to provide care. However, one could argue that the present fee-for-service system provides incentives to over-utilize which may be just as unethical. For a comment on the loss of physician autonomy due to cost containment see $\mathrm{W}$. Stilling, "Who's In Charge: The Doctor or the Dollar? Assessing the Relative Liability of Third Party Payors and Doctors After Wickline and Wilson" (1992) 18 J. Contemp. L. 285 at 298 who noted as follows:

The cultural authority that physicians possess provides the profession with almost limitless autonomy. However, cost-containment programs place constraints on physicians' autonomy. As economic considerations influence medical decisions to a greater extent, physicians will lose their autonomy as gatekeepers for the medical system. Challenges to Decision Making" (Presented at the Canadian Institute for the Administration of Justice, October 1990).

This is one method the provinces have used to try and contain their health care budgets. See generally J. Hughes, "How Well Has Canada Contained the Costs of Doctoring?" (1991) 265 JAMA 2347. See also Barer, supra note 6 at 2393; and R. Barer \& R. Evans, "Riding North on a South-Bound Horse? Expenditure, Prices, Utilization and Incomes in the Canadian Health Care System" in R. Evans \& G. Stoddard, eds., Medicare at Maturity (Calgary: The University of Calgary Press, 1986) at 90-98, where the provincial variation in physician income patterns is noted. 
insurance.9 Because of this "hands off approach", physicians have been free to prescribe whatever treatments they might deem necessary with little concern for cost or resource limitations. ${ }^{10}$ The result has been a theoretically ideal situation where the best interest of the patient could be the all-encompassing motivational force. "It has been in this atmosphere that the legal doctrines, specifically the standard of care, surrounding medical malpractice developed. (The present standards will be discussed more fully below.) However, the current push to control the provincial and federal budgets has created a situation where limitations on the availability of medical resources may become a common occurrence. This trend is exemplified by Alberta's plans to re-examine what should be covered by its provincial insurance plan. ${ }^{12}$

Hospital administrations can also place cost containment pressure on physicians. ${ }^{13}$ In Canada, hospitals receive almost all of their operating budgets from their respective provincial government. ${ }^{14}$ Due to the cost containment movement, these budgets are dwindling. ${ }^{15}$ This, in turn, has led to increased pressure on physicians working within these institutions to practice more efficiently and economically. ${ }^{16}$ In fact, a recent

See Rivet \& Preus, supra note 7 at 4 , who noted that "neither clinical decisions nor treatment protocols are reviewed by the responsible ministries but aggregate billing must be within the negotiated limits."

10 D. Naylor \& A. Linton, "Allocation of health care resources: a challenge for the medical profession" (1986) 134 CMAJ 333 at 334-335; and G. Stoddart \& M. Barer, "Toward integrated medical resource policies for Canada: 10. Information creation and dissemination" (1992) 147 CMAJ 1325 at 1327 . See also S. Salloum \& E. Franssen, "Laboratory Investigations in General Practice" (1993) 39 Can. Fam. Phys. 1055 at 1058-59, where it is reported that "as a group, the physicians had very little sense of the cost of laboratory investigation." Further, few Canadian physicians view the cost of medical services as a serious problem in Canada, see $\mathrm{R}$. Blendon $e t$ al., "Physicians' Perspectives on Caring for Patients in the United States, Canada, and West Germany" (1993) 328 New Eng. J. Med. 1011 at 1013.

"In reality, of course, other forces such as defensive medicine and economic gain also played a role to a greater or lesser extent. For an example of the effects of potential monetary gain on the referral patterns of physicians in the United States see J. Mitchell \& J. Sunshine, "Consequences of Physicians' Ownership of Health Care Facilities - Joint Ventures in Radiation Therapy" (1992) 327 New Eng. J. Med. at 1497. See also W. Davidson et al., "Relation between physician characteristics and prescribing for elderly people in New Brunswick" (1994) 150 CMAJ 917; and M. Chren \& S. Landefeld, "Physicians' Behaviour and Their Interactions With Drug Companies" (1994) 271 JAMA 684.

12 S. Feschuk, "MLAs want user fees on non-essential care" The [Toronto] Globe and Mail (10 December 1993) A7.

13 Physicians in hospital settings experience more cost containment pressure than physicians in private practice: Williams \& Beresford, supra note 6 at 307.

14 M. Brown, "Rationing Health Care in Canada" (1993) 2 Ann. Health L. 101 at 113-14.

is In fact, many hospitals are operating with deficits and therefore are exploring various cost containment strategies. Rachlis \& Kushner, supra note 3 at 30, where it is noted that in Ontario 117 out 222 hospitals are in a deficit in 1988. See also Brown, ibid; and A. Linton, "Will Health Care Need to be Rationed?" 59:1 Ont. Med. Rev. 5 at 6.

16 It is interesting to note that physicians, on the other hand, are usually financed on a fee-for-service basis and, as a result, have little or no economic motivation to adjust their practice patterns in order to accommodate the limitations imposed by a hospital fixed budget system. This conflict between Canadian physicians and hospitals has been outlined by J. Igleharh, "Canada's Health Care System" (1986) 315 New Eng. J. Med. 778 at 783, in the following manner:

Hospitals, which have fixed global budgets, and physicians, whose incomes rise if they deliver more services, operate under conflicting incentives in the 
study demonstrates that Canadian physicians may already be adjusting their practices as a result of cost containment pressure. ${ }^{17}$ The physicians interviewed for the study indicated that shortages in staff, equipment, drugs and diagnostic tests were all areas of concern. ${ }^{18}$ Perhaps the most important revelation in the study is the fact that physicians felt the quality of care had already been adversely affected. ${ }^{19}$ (In general, physicians blamed hospitals for the shortages and cost containment pressure). For the purposes of this article it is interesting to note that all of the items rationed could possibly lead to malpractice exposure if a physician failed to use them in appropriate circumstances. ${ }^{20}$

Other examples of institutional pressure to conserve include the development of utilization review committees, ${ }^{21}$ the presence of waiting lists for various surgical procedures $^{22}$ and a reduction in the granting of hospital privileges to physicians. ${ }^{23}$

Despite this third party pressure, "[s]o long as the physician retains the power of decision making necessary for good health care, he [or she] is ipso facto a key agent

inpatient setting; thus, tension often marks their relationship.

Williams \& Beresford, supra note 6.

Jbid. at 306-307.

Ibid.

Ibid.

See L. Milner, "Cost Containment: Criteria for Physician Standard of Care and Need for Documentation of Expert Witness Experiencen (1989) 35 Med. Tr. T.Q. 1 at 3-7 [hereinafter "Criteria for Physician Standard of Care"] for a discussion of Professional Standards Review Organizations and Health Maintenance Organizations and their effects on physician autonomy and the medical standard of care. See also J. Blum, "An analysis of the legal liability in health care utilization review and care management" (1989) 26 Hous. L. Rev. 191 at 194-97, for a discussion of government sponsored utilization review committees as a means of controlling health care costs; and R. Mickleburgh, "Study Calls ECG Waste of Money" (12 May 93) The [Toronto] Globe and Mail A1-A4, where it is reported that Saskatchewan's Health Services Utilization and Research Commission has set guidelines to reduce the number of ineffective medical procedures performed. In addition, see T. Marmur \& D. Boyum, "American Medical Care Reform: Are We Doomed to Fail?" (1992) Working Paper for the Canadian Institute for Advanced Research at 176. See generally Perspectives On Implementing Utilization Management Initiatives In Canadian Health Care Facilities (Canadian Council On Health Facilities Accreditation, 1992); and Blendon et al., supra note 10 at 1015 , where it was noted that physicians do not particularly enjoy utilization review. In the United States, where utilization review is more common, 53 percent of physicians reported that "external review of clinical decisions for the purpose of controlling health care costs" was a serious problem. Only 28 percent of Canadian physicians felt this was a serious problem. Personal communication Dr. G.R. Langley, Department of Medicine, Dalhousie University and Victoria General Hospital, January 1993. A number of actions have been commenced in response to surgical waiting lists. There is presently an action in British Columbia that was commenced after a woman died on a waiting list for cardiac surgery (Sallis v. Vancouver General Hospital, No. C907316, Vancouver Registry) [hereinafter Sallis], personal communication with plaintiff counsel, David Bellamy, December 1992 and November 1993. See also F. Rozovsky, "The Legal Case Against Rationing Necessary Health Care: Ethical and Policy Implications" (1992) (presented at the "Struggle to Decide" Symposium, Cape Breton, Nova Scotia, September 1992) at 3.

See Brown, supra note 14. 
of resource allocation." 24 And for this reason, physicians will undoubtedly be a primary focus of cost containment litigation. ${ }^{25}$

\section{EROSION OF THE PATIENT'S TRUST}

Another factor which is likely to make physicians a primary focus of cost containment malpractice actions, and lead to greater liability exposure, is the erosion of the trust involved in the physician/patient relationship. ${ }^{26}$ This is particularly true since the nature of the clinical relationship evolved at a time when the majority of Canadian patients have become accustomed to apparently "free" medicine.

Giving physicians the duty of allocating resources may place them in a position involving a conflict of interest. ${ }^{27}$ They may be asked to make decisions which consider not only the needs of their patients but also the needs of society as a whole. ${ }^{28}$ This tension was discussed by a Canadian physician as follows:

Now the physician - patient relation is being strained by the fact that physicians are being asked to consider the cost of care they are providing and at the same time remain the patient advocate. ${ }^{29}$

24 "Cost Containment", supra note 5 at 1729.

2s For example see J. Lairson, "Reexamining the Physician's Duty of Care in Response to Medicare's Prospective Payment System" (1987) 62 Wash. L. Rev. 791 at 804, where the author notes that in the United States "the physician, not the hospital or Medicare, continues to make and will continue to be liable for treatment and discharge decisions, even when reimbursement will not fully cover the cost."

26 See generally J. David, "Doctor-patient relationship put under microscope at CMA leadership conference" (1993) 148 CMAJ 1787, where it is noted that the physician-patient relationship is already under a great deal of strain; See also $\mathrm{R}$. Whitehead, "The Effect of Malpractice Legislation on the Doctor-Patient Relationship" (1993) 40 Med. Tr. T.Q. 170 at 183 where it is suggested as follows:

'[M]ore malpractice suits have been precipitated by the breakdown of the physician-patient relationship than by any other condition.' Thus, a solution to the malpractice crisis is the maintenance of this relationship, or the doctor's demonstration of understanding, caring, and compassion for the patient at every opportunity.

For example, The Canadian Medical Assoc. Code of Ethics (Ottawa: The Canadian Medical Association, 1990) declares that the first principle of Ethical Behaviour is to "consider first the well-being of the patient"; and the American College of Physicians Ethics Manual (1992) 117 Ann. Internal Med. 947 at 948 wherein it is stated that "[t]he patient's welfare and best interests must be the physician's main concern." See also Agich, supra note 4; "Cost Containment", supra note 5 at 1727; and R. Veatch, "Physicians and Cost Containment: The Ethical Conflict" (1990) 30 Jurimetrics J. 461; and Stilling, supra note 6 at 301 where the author notes that the American Medical Association "believes that the beneficence principle must override any cost considerations at the level of physician-patient interactions."

See Linton, supra note 15 at 8; and M. Somerville, "Ethics and clinical practice guidelines" (1993) 148 CMAJ 1133 at 1134, where the author notes that "although the physician's obligation of personal care to the patient is primary, physicians also have obligations to others, including the community."

29 E. Wigle, "Convocation Lecture: The Rationing and the Rationalization of Cardiac Care American or Canadian Style?" (1988) 12 J. Am. Card. 572 at 575. 
Patients may become cognizant of this conflict and thereby come to the realization that their physicians' judgment is sometimes being affected by factors outside the best interests of the patient. ${ }^{30}$

Will this increase in patient/physician tension create greater liability exposure? It seems inevitable that it must. If individuals feel they have received inadequate care as a result of cost containment pressure they are likely to want to blame someone and their physician, as the bearer of the bad economic news, is the obvious target. As commented by Miller:

As patients become more aware that they may be the targets of rationing, anger and frustration derived from their helplessness are likely to be focused on the nearest targets - the physician-gatekeeper as de facto enemy.... 31

Another factor which may be placing increased pressure on physicians is the fact that the characteristics of patients are changing. There are a growing number of patients that are no longer prepared to receive treatment advice passively from their physicians. ${ }^{32}$ Increasingly, patients are becoming more actively involved in the decision making process. These patients are generally better informed, more confrontational and are more likely to be aware of treatment alternatives.

R. Veatch, "Allocating Health Resources Ethically: New Roles for Administrators and Clinicians" (1991) 8:1 Front. of Health Serv. Mgmt. 3 at 7-8 and 27 [hereinafter "Allocating Health Resources"] who believes that this conflict of interest created by the allocation of medical resources is so great that physicians should not be required to make these decisions as they should not do "society's dirty work". See generally P. Menzel, "Some Ethical Costs of Rationing" (1992) 20 L. Med. \& Health Care 57 for a criticism of this view. See also Williams \& Beresford, supra note 6 at 308 whose study indicates that some Canadian physicians are reluctant to refuse unreasonable patient requests for fear of weakening the patient's confidence. Adding to this phenomenon is the reality that explicit rationing, which is a patently aggressive cost containment strategy, may appear to patients as a process that is discriminatory in nature. See R. Evans, "Rationale for Rationing" (1992) 14 Health Mgmt. Q. 14 at 16 where the author argues that the concept of "cost-effectiveness" is discriminatory because it involves a process of economically valuing humans.

31 F. Miller, "Denial of Health Care and Informed Consent in English and American Law" (1992) $18 \mathrm{Am}$. J. L. \& Med. 37 at 71 . Miller goes on to argue that expanding the informed consent duty of the physician is the best way to eliminate this problem.

32 G. Bagley, "Patient profiles are changing - are you ready?" (1992) 2 Wellness MD 17 at 18 . In this article the author cites data showing that the percentage of "health-active, self-responsible patients" is on the increase. See also Friedman, supra note 2 at 13; and Miller, ibid. at 68-69, for a general discussion of how patients in Britain are becoming more active. See also Williams \& Beresford, supra note 6 and G. Langley et al., "Effect of nonmedical factors on family physicians' decisions about referral for consultation" (1992) 147 CMAJ 659; and Salloum \& Franssen, supra note 10, for a review of studies that outline the impact of patient expectations and wishes on treatment patterns. Finally, see the Royal Commission on New Reproductive Technologies, supra note 4 at 30-31, where the authors note:

The empowerment of individuals thus has implications for traditional doctor/patient relationships. Individuals are no longer as accepting or trustful of "experts", particularly in fields such as medicine where the consumer movement has influenced people's perception of how they can participate in their own care. 
Adding to this phenomenon is the fact that patients' expectations of the medical profession have increased. ${ }^{33}$ This trend was investigated in a study of Canadian physicians undertaken by Salloum. She found that:

[m]ost physicians ( 89 percent) indicated that they believed patient expectations and demands influenced their test-ordering behaviour. Of these physicians, 8 percent thought their test-ordering behaviour was strongly influenced by patient expectations. Moreover, 73 percent of the physicians believed patients expect more tests now than they did 10 years ago. Almost all ( 92 percent) believed there was a greater risk of involvement in litigation now than 10 years ago, and 91 percent of the group believed their testordering behaviour was affected by this perceived risk of litigation. ${ }^{34}$

It is interesting to note that in addition to physicians' belief that there has been a change in patient expectations over the last ten years, there was also an increase in the perceived risk of litigation. Although the study does not correlate these two variables (i.e. perceived risk of litigation and increased patient expectations), the connection seems natural.

Whether a more proactive, expectant and informed patient will be more prone to sue a physician is unclear. However, it has been suggested that as patients' knowledge regarding the medical profession's capabilities grows, they are more likely to blame physicians when something goes wrong. ${ }^{35}$

\section{DISCUSSION}

The cumulative effect of the above-mentioned factors will likely be two-fold. First, they increase the prospect that physicians will be targets of cost containment litigation.

Bagley, ibid. at 17. See also P. Meagher, "Our health-care system takes heavy toll on MDs" (1993) 5 Fam. Pract. 15 at 15, where the author notes the public's "increasing expectations of high technology and the illusion that physicians' can cure anything..."; and Blendon et al., supra note 10 at 1013, where a study by the authors found that 66 percent of Canadian physicians thought that "patients' demands for more services than doctors thought clinically necessary was a serious problem." Patients may also be getting more involved at the public policy level as reflected in many of the provinces' health care system reports which call for increased public input in the health care decision making process. For example, the Nova Scotia Provincial Health Council (August 1992), enumerates six health goals including the opportunity for "all of us to participate in making decisions about our health care system." In The Government of Alberta's Response to the Premier's Commission on the Future Health Care for Albertans (November 1991) [hereinafter Alberta's Response], the provincial government recognized that "Albertans are now asking for a more active role in determining the future direction of health care in Alberta." The government supported this position. See also Working Together to Achieve Better Health For All: Southwestern Ontario Comprehensive Health System Planning Commission (December 1991) at 55 [hereinafter Ontario Comprehensive Health]. Also, many Canadian commentators have recognized the need for more public input. For example, Stoddart \& Barer, supra note 10 at 1327; and Linton, supra note 15 at 8. However, see R. Klein, "Dilemmas and Decisions" (1992) 14 Health Mgmt. Q. 2 at 5 , who argues that a lack of visibility may be needed for health carc resource allocation decision or they will become too politicized.

34 Salloum \& Franssen, supra note 10 at 1058.

3s Harvard, supra note 5 at 1010; and I. Press, "The Predisposition to File Claims: The Patient's Perspective" (1984) 12 L. Med. \& Health Care 53 at 53. 
Second, they place unique pressures on physicians, which will make the practice of medicine increasingly difficult in the coming years. ${ }^{36}$ The stress these conflicting pressures have on physicians is summarized by Dr. Carole Guzman, former president of the Canadian Medical Association, as follows:

Growing intervention is making it harder to act in the patient's best interest. There is a strain when you feel pounded on the one side by the need to conserve resources, to be efficient, and on the other side to satisfy the expectations of the public. ${ }^{37}$

Nevertheless, regardless of the extent of the outside pressure for cost containment, it is ultimately the physician who makes the "medical" decision ${ }^{38}$ and he/she will be held legally accountable if such decisions are made negligently. ${ }^{39}$

\section{WILL LIABILITY BE IMPOSED ON PHYSICIANS?}

\section{A. THE REAL AND PERCEIVED LOWERING OF THE QUALITY OF CARE}

At first blush it would seem that in order for there to be a legal impact on the medical community as a result of cost containment, there must be a decrease in the actual quality of health care. However, it has been noted that cost containment need not impact the quality of care. ${ }^{40}$ In fact, it could be argued that a cost containment program would actually increase the quality of care by forcing physicians to stop unnecessary practices and procedures. ${ }^{41}$

Some have suggested that these pressures may "place physicians under inappropriate and unfair economic and legal pressures." E. Morreim, "Stratified Scarcity: Redefining the Standard of Care" (1989) 17 L. Med. \& Health Care 356 at 356 [hereinafter "Stratified Scarcity"]. See also "Allocating Health Resources", supra note 30 at 27. In Meagher, supra note 33 at 15.

38 Wickline v. State of California, 228 Cal. Rptr. 661 (Cal. App. 2 Dist. 1986) at 671-72 [hereinafter Wickline]. The court noted that if the attending physician's medical opinion and the third party payors decision differed greatly then it would be the duty of the physician to "make some effort" to obtain the resources. As will be seen below, this "economic advocacy" role may be an added duty imposed on the physician as a result of cost containment. The individual responsibility of physicians was noted by Somerville, supra note 28 at 1134 , as follows:

[I]t is the nature, privilege and responsibility of a profession that there be an exercise of individual and independent judgement in each case in which a professional is involved. In other words, in both ethics and law there is no defence of obedience to higher orders for professionals, nor should there be one.

39 For example see Lairson, supra note 25 at 804.

40 For example see M. Kapp, "Health Care Delivery and the Elderly: Teaching Old Patients New Tricks" (1987) 17 Cumberland L. Rev. 437 at 449-50.

4 One could argue that the fee-for-service system encourages physicians to perform unnecessary treatments which expose patients to the potential for an iatrogenic injury. In this context, cost containment may be a dose of reality. 
Although this may be true in the short term, cost containment in health care will not be a "one shot" proposition. ${ }^{42}$ It will require an ongoing commitment to effective resource allocation and management which may result in the implementation of policies that require the withholding of beneficial medical treatment. ${ }^{43}$ This is particularly true since the cost of providing "the best possible care" is increasing with each technological advancement. ${ }^{44}$ At the very least, we will probably be asking physicians to provide care below that which is technologically possible. ${ }^{45}$ Whether this will force physicians to practice below the legal standard of care will be examined below.

However, even if costs can be cut without affecting quality, there may still be an impact on the number of medical malpractice actions. The patient's perception of the quality of the care received is an important component of the malpractice equation. ${ }^{46}$ Cost containment is becoming increasingly topical and has received a large amount of exposure in the popular media. Logically, this will result in patients who are more cognizant about health care generally and who are perhaps increasingly suspicious of being subjected to care that has or may have been constrained by cost containment policies. Explicit rationing programs would further enhance this awareness, particularly if they involved highly visible health care items. This may, in turn, lead to an increase in malpractice suits regardless of whether there is an actual reduction in the quality of care.

As one commentator has stated:

See H. Aaron \& W. Schwartz, "Rationing Health Care: The Choice Before Us" (1990) 247 Science 418 at 419; and K. Pennar, "A Crisis of Medical Success" (March 1993) Business Week 78 at 78. See generally D. Callahan, "Symbols, Rationality, and Justice: Rationing Health Care" (1992) 18 Am. J. Med. 1; and "Allocating Health Resources", supra note 30, as examples of authors who feel that the need to ration health care is inevitable. See generally Aaron \& Schwartz, supra note 42.

Harvard, supra note 5 at 1004. See also H. Emson, "Down the Oregon trail: The way for Canada?" (1991) 145 CMAJ 1441 at 1441, where the author notes that "the cost of human ingenuity applied to health care exceeds the capacity to pay for it. The effects of this disparity are unpleasant. One is that not everyone receives all the health care from which they might benefit...." V. Fuchs, "No Pain, No Gain: Perspectives on Cost Containment" (1993) 269 JAMA 631 at 631-32, suggests that the area of medicine that has the "greatest impact on expenditures" is "low yield" medicine. "These are the services that do provide some patient benefit, but the value to the patient is less than the cost to society of providing them." He also notes that it is "this kind of medical care that is the most difficult to constrain." See also P.W. Kryworuk et al., "Potential Legal Liability in the Allocation of Scarce Health Care Resources" (1994) 14 Health L. Can. 95.

46 See generally Press, supra note 35. Of course, physicians' perceptions of the threat of litigation are also important to the cost containment equation (i.e. defensive medicine). And, as is the case with patients, the "belief" in the existence of a threat may be just as important as an actual increase in liability exposure. For instance, in one Canadian study it was reported that physicians "believed" that the threat of litigation had increased significantly over the last ten years and that this belief "affected their test-ordering behaviour." See Salloum \& Franssen, supra note 10. In fact, during the ten years studied (1979-1989) there was only a modest increase in the incidence of litigation and between 1985 and 1989 the number of lawsuits actually decreased. In other words, physicians' use of defensive medicine techniques increased despite the fact that the likelihood of being sued decreased. 
Patients' expectations of physicians are based almost wholly on patient's beliefs, attitudes, and psychosocial needs - not knowledge of appropriate professional behavioral standards. ${ }^{47}$

On this basis, one could speculate that cost containment's impact on patients' perceptions would have a number of major effects. For instance, cost containment might "bring out" the patients with meritorious claims who otherwise would never commence actions. Currently, only a fraction of the potential malpractice plaintiffs ever file a claim despite having been negligently injured by their health care providers. ${ }^{48}$ Therefore, a reduction in the quality of care may not be needed in order to introduce new malpractice issues since the perceived change in patient care may induce more patients with valid claims to commence actions. ${ }^{49}$

Press, ibid. at 55. See also Whitehead, supra note 26 at 183 where the author suggests that there is "little correlation between what a doctor does and whether a patient sues." Rather, he believes "it is based on feelings of disapproval, betrayal, and resentment of a poor doctor-patient relationship." It is interesting to note that at present Canadians are relatively happy with their health care system. See Iglehart, supra note 16 at 781; and R. Elgie, "Prologue" in J. Greenwood \& A. Tarrco, eds., Workers' Compensation Health Care Cost Containment 6 (Horsham: LRP Publications, 1991) at 11, where it was noted that Canadians had the highest public satisfaction with their health care system at 56 percent while the United States was the lowest with 10 percent. See also R. Blendon \& K. Donelon, "Public Opinion and Efforts to Reform the United States Health Care System: Confronting Issues of Cost Containment and Access to Care" (1992) 3 Stanford L. \& Pol. Rev. 146 at 147. Despite the call for health care reform, Canadian physicians are relatively happy with their health care systems as compared with United State's physicians, see Blendon et al., supra note 10 at 1012 and L. Landry, "Physicians' perspectives on health reform revealed in CMA-sponsored survey" (1993) 149 CMAJ 879.

See R. Elgie et al., "Medical Injuries and Malpractice: Is it Time for No-fault?" (1993) 1 Health L. J. 97 at 99-100; and A. Lawthers, "Physicians' Perceptions of the Risk of Being Sued" (1992) 17 J. Health Pol. 463 at 463. See also J.R. Prichard, Liability and Compensation in Health Care (A Report to the Conference of the Ministers of Health of the Federal/Provincial/ Territorial Review on Liability and Compensation in Health Care, 1990) at 17, where it was estimated that less than 10 percent of viable claims result in compensation through the tort system. See also B. Dickens, "The Effects of Legal Liability on Physicians' Services"(1991) 41 U. Toronto L.J. 168 at 222. However, socio-economic factors also play a large part in whether a given individual will commence a malpractice suit. See H. Burstin et al., "Do the Poor Sue More?: A Case-Control Study of Malpractice Claims and Socioeconomic Status" (1993) 270 JAMA 1697. It is questionable whether cost containment will increase the frequency of claims from the "poor". In addition, it could be argued that the implementation of cost containment programs would further increase physicians' beliefs that there is a growing threat of litigation, regardless of whether a given program actually resulted in the lowering of the quality of care. This is because many physicians may "believe" there is a reduction in the quality of care as a result of cost containment. Therefore, physicians will arguably feel the need to shield themselves from any additional liability exposure which may flow from cost containment. As a result, defensive medicine could continue to intensify at a rate independent of any true impact on the quality of care. Also, the change in patient perceptions, which will arguably accompany cost containment, may also intensify physicians' belief in the need for defensive medicine. Since cost containment programs will probably target many of the items that are often associated with defensive medicine (e.g. unnecessary tests and referrals) it will be interesting to see if physicians find novel ways to practice defensive medicine. One wonders whether the novel techniques will be as costly as the present defensive medicine practices. 


\section{B. SUING PHYSICIANS FOR SUBSTANDARD HEALTH CARE}

If the quality of health care does decrease due to the present trend to contain costs, which seems inevitable, then patients may react to these changes by utilizing the tort system. However, if the tort system is capable of adjusting to these changes, for example, by reducing the legal standard of care, then patient-initiated cost containment actions may prove unsuccessful. The next section of this article will review the relevant negligence law and analyze how it may react to the cost containment trend in ways that may frustrate attempts by patients to protect their access to health care.

\section{Legal Background}

A legal action against a physician for "sub-standard" health care can take a variety of forms. When a physician/patient relationship exists, the physician owes a variety of legal duties to the patient and a breach of any of them may constitute negligence. ${ }^{50}$ In addition, there is a contractual relationship between a physician and his/her patient that may support an action in contract. ${ }^{\text {s1 }}$ The fiduciary duty, which arises from the relationship of trust and reliance between a physician and a patient, may also give rise to an action if the obligations which flow from that relationship are not fulfilled. ${ }^{52}$ While all of these areas of potential liability may be affected by cost containment pressure, this article will focus primarily on tort liability.

In a medical malpractice actions, the successful plaintiff must establish that: ${ }^{53}$

1) the defendant owed a duty of care to the plaintiff;

2) the defendant breached the standard of care;

3) the plaintiff must suffer an injury or loss;

4) the defendant's conduct must have been the actual and legal cause of the plaintiffs injury. ${ }^{54}$

See generally A. Meagher et al., Doctors and Hospitals: Legal Duties (Toronto: Butterworths, 1991); and E. Picard, Legal Liability of Doctors and Hospitals in Canada (Toronto: Carswell, 1984) at 200-228.

s1 G. Robertson, "Reform of the Law of Medical Liability: The Position in the Common Law Jurisdictions of Canada" (Montreal: International Congress of Comparative Law, 1990) 173 at 18081 [hereinafter "Law of Medical Liability"]. It is also possible that claims based on contractual principles could be affected by cost containment in health care. When an individual has a private insurance contract and is subjected to cost containment practices by the private insurer, the terms of the contract may be at issue. For example, see Hughes v. Blue Cross of Northern California, 215 Cal. App.3d 851 at 858-59 (Cal. App. 1 Dist., 1988). In that case the issue revolved around the interpretation of a term in the policy regarding what was considered "medically necessary". For example Henderson v. Johnston, [1956] 5 D.L.R. 524 (Ont. H.C.J.), aff d [1957] 11 D.L.R. (2d) 19 (C.A.), aff d (1959), 19 D.L.R. (2d) 201 (S.C.R.) for a discussion of the fiduciary relationship. See also Norberg v. Wynrib, infra note 184; and Mclnerney v. MacDonald (1992), 2 S.C.R. 138, where the Supreme Court emphasizes the physician's fiduciary duties to the patient. Picard, supra note 50 at 150; and Robertson, supra note 51 at 174. 
In general, it is rarely a problem to establish that a duty existed at the time of an injury if there is a physician/patient relationship. The courts have been relatively liberal with the interpretation of the circumstances in which this type of relationship may arise. ${ }^{55}$ For example, a physician/patient relationship may be established when a patient simply walks into a emergency ward requesting assistance. ${ }^{56}$

Proving the causal relationship can be somewhat more problematic. The plaintiff has the burden of satisfying the court that the defendant's negligence caused his/her loss. ${ }^{57}$ Although a court may infer causation if the defendant does not advance evidence to the contrary, this may still be an onerous task given the complexity of the subject matter. ${ }^{58}$ It is unlikely that cost containment will have a direct impact on the nature of this test, however, as will be seen below, it may arise as an issue in establishing a "cost containment" case.

If causation is not at issue, then a medical negligence case really involves establishing the legal standard of care and determining whether the defendant physician satisfied that standard in the situation in question. ${ }^{59}$ This is a question of fact for the judge or jury and generally "lies at the heart of every negligence suit."160 If the defendant demonstrates that he or she did not fall below this standard, then there has been no negligence. Since cost containment will likely result in an adjustment of "medical customs" - which are relevant to establishing the standard of care - we will focus on this aspect of the malpractice equation.

\section{The Medical Standard of Care}

In Canada, the standard of care which physicians have traditionally been expected to meet can be summarized as follows:

Every health practitioner must bring to his task a reasonable degree of skill and knowledge, and must exercise a reasonable degree of care. He is bound to exercise that degree of care and skill which could reasonably be expected of a normal, prudent practitioner of the same experience and standing. ${ }^{61}$

While the court would ordinarily determine the "legal" standard of care by examining medical custom through testimony from expert witnesses, it is not bound to do so.62

Meagher et al., supra note 50 at 4-5; and Picard, supra note 50 at 4.

Meagher $e t$ al., ibid. at 4-5.

See Snell v. Farrell, supra note 54; and see generally Picard, supra note 50 at 183-200.

Snell v. Farrell, ibid. at 301.

J. Blumstein, "Rationing Medical Resources: A Constitutional, Legal, and Policy Analysis" (1981) 59 Tex. L. Rev. 1345 at 1395.

Picard, supra note 50 at 154.

Crits v. Sylvester, [1956] O.R. 132 at 143 (C.A.), affd [1956] S.C.R. 991 at 997. See also McCormick v. Marcotte, [1972] S.C.R. 18 at 21; Wilson v. Swanson, [1956] S.C.R. 804 at 817.

For example Anderson v. Chasney (1949), 4 D.L.R. 71 (C.A.), affd (1950), 4 D.L.R. 233 (S.C.C.) [hereinafter Anderson]. See J.G. Fleming, The Law of Torts, 6th ed. (Sydney: The Law Book Company, 1983) at 114, where he notes that "accepted practice is open for censure by a jury." See also Edmison v. Boyd (1987), 51 Alta. L.R. 43 at 45 (Alta. C.A.), where the court applied Anderson noting that this was "not a case where expert testimony is conclusive but rather where 
However, a court will rarely find a physician liable if he/she has not deviated from the medical custom. ${ }^{63}$

As stated above, the standard of care was established at a time when there was no economic constraint on access to medical resources. This has caused some to question the wisdom of using the same test in an era of cost containment. ${ }^{64}$ Also, the standard of care has become more stringent due to technological advances which have now become part of the medical standard. ${ }^{65}$ As a result, it may be relatively easy for patients/plaintiffs to establish that their physicians practice below the "medical custom" - particularly if they are denied access to a medical technology that was once viewed as part of the medical custom.

The introduction of new technologies does not automatically raise the standard of care nor are physicians expected to adopt new procedures immediately. ${ }^{66}$ However, once they are in common use they cannot be ignored ${ }^{67}$ and a doctor who chooses an obsolete method may not meet the standard of care. ${ }^{68}$ Given the media attention that medical advances are now receiving, the public expects the implementation of these techniques as soon as practicable. Also, one could argue that the corporations producing the new technologies have a vested interest in ensuring that they become items of "common use". ${ }^{69}$ Therefore, technologies can become part of the medical custom relatively quickly. As Picard states: "many inventions now taken for granted were innovations a short time ago." ${ }^{170}$ This, in itself, does not preclude physicians from using older medical techniques or tools, but if they do they must take extra precautions

common sense dictates."

63 See Blumstein, supra note 59 at 1396; and Robertson, supra note 51 at 176.

64 For example Harvard, supra note 5 at 1008.

6s See Robertson, supra note 51 at 175 , where the author notes "the standard is becoming increasingly demanding, as new technology and learning evolve." See also "Cost Containment", supra note 5 at 1724; and "Stratified Scarcity", supra note 36 at 357.

See generally Picard, supra note 50 at 170 .

For example see Lee v. O'Farrell (1988), 43 C.C.L.T. 269; and Menzies v. Harlos (1989), B.C.W.L.D. 1741 .

McCormick v. Marcotte, supra note 61 at 21-22.

For example see B. Meier, "Effective? Maybe. Profitable? Clearly." The New York Times (14 February 1993) at F1, where the author notes the profitability of medical devices. "Medical companies often go to great lengths to encourage doctors to use their products, and to persuade insurance companies to pay for them. And they can succeed even when significant questions exist about a products efficacy and safety." See also N. Jecker \& L. Schneiderman, "Futility and Rationing" (1990) 92 Am. J. Med. 189 at 190, where the authors note that other non-medical factors contribute to the use of technology. They state: "Enthrallment with new technologies, together with the prestige sometimes associated with them, may encourage excessive use, thereby exacerbating the ethical problem of using technology under futile circumstances." See Fuchs, supra note 45 at 632, where he notes: "Are radiologists likely to recommend fewer radiological services? Both their desire to use their hard-won technical skills and their desire to preserve their incomes suggest otherwise. Will transplant surgeons welcome measures to reduce the number of transplantations? Not likely." 
to meet the standard of care. "Why would a physician take that risk if more advanced, and usually more expensive, treatments are available?

Technological advances attract much of the blame for the continuing rise in health care costs. ${ }^{72}$ Therefore, this is one area that will certainly be scrutinized for possible cost containment programs. ${ }^{73}$ Admittedly, this is a logical area for the introduction of cost containment measures since it seems likely that for a number of ailments the medical custom, which is relevant to the determination of the legal standard, may be unnecessarily aggressive, intrusive, and expensive. ${ }^{74}$ Many "high tech" treatments have been adopted as normal medical practice despite the fact that older, and less expensive, procedures may still be as effective for the majority of patients. ${ }^{75}$

See LaFleur v. Cornelis (1979), 28 N.B.R. 569 at $574-75$ (N.B.Q.B), where a physician used an older, more risky technique. The court found he was negligent not for using the older technique but for failing to take extra precautions. However, note that if a physician uses the most innovative techniques he/she must also meet a higher standard of care, e.g., Zimmer v. Ringrose (1978), 89 D.L.R. (3d) 646, aff'd (1981), 16 C.C.L.T. 51 (Alta. C.A.); and Murphy v. St. Catharine General Hospital (1964), 41 D.L.R. (2d) 697 at 703 and 714-718. See also Picard, ibid. at 170. See E. Godley, "MDs should assume more responsibility for managing health care, Royal College audience told" (1994) 150 CMAJ 76 at 77. See also Harstall, supra note 4 at 26.

Example R. Evans, "Health Care Technology and the Inevitability of Resource Allocation and Rationing Decisions" (1983) 249 JAMA 2047 [hereinafter "Health Care Technology"]. Both Alberta's and Ontario's provincial reports on health care discuss a redistribution of funds to more "low tech" projects like health promotion. See Alberta's Response, supra note 33 at 23; and Ontario Comprehensive Health, supra note 33 at 115-31 and at 143-48. While "high tech" medicine is likely to be a target of cost containment measures, cutbacks will not be easily obtained. Physicians will undoubtedly guard their practices; see Fuchs, supra note 45 at 632 . See for example Jecker \& Schneiderman, supra note 69 at 190-91; and D. Dewees \& $M$. Trebilcock, "The Efficacy of the Tort System and its Alternatives: A Review of Empirical Evidence" (1992) 30 Osgoode Hall L.J. 57 at 82. See also Ginzberg, supra note 4 at 199 where it is noted that there is presently a growing movement calling for increased outcome studies as a mechanism of controlling health care costs. In addition see A. Relman, "Reforming the Health Care System" (1990) 323 New Eng. J. Med. 991 at 992; Stoddart \& Barer, supra note 10 at 1326; The Royal Commission on New Reproductive Technologies, supra note 4 at 70-72; and Wennberg, supra note 4. See also Gibson, supra note 4, where the author comments on the lack of outcome research and the continued utilization of therapies and procedures which have no proven benefit (e.g. cholesterol testing, treatments for common colds, ultra sound for low risk pregnancies, X-rays for minor injuries, routine mammograms, and the overuse of antibiotics); and Brown, supra 14 at 107 where he notes:

The current state of scientific knowledge about the comparative clinical effectiveness, cost-effectiveness and program effectiveness of alternative interventions for various acute and chronic states of ill health and various health promotion and prevention programs is incomplete at best.

As noted by F. Lowy, "Restructuring Health Care: Rationing and Compromise" (1992) 8 Humane Med. 2630 at 266: "[W]e cannot continue the routine use of the latest and most expensive diagnostic technology or pharmaceutical products when these are only marginally superior to less expensive, perfectly acceptable alternatives." See also J. Rouleau, "A Comparison of Managed Patterns After Acute Myocardial Infarctions in Canada and the United States" (1993) 328 New Eng. J. Med. 779 at 782-84. These authors note marked differences in cardiac care between the United States and Canada despite similar patient outcomes. Regional treatment differences for other diseases are reviewed in Grogan, supra note 4. See generally Wennberg, ibid; and Jecker \& Schneiderman, ibid. at 190-91, on the use of high technology in futile situations; and C. Winslow et al., "The Appropriateness of Performing Coronary Artery Bypass Surgery" (1988) 260 
Since the court generally accepts whatever is the established "medical custom" as the legal standard of care, ${ }^{76}$ one could surmise that the legal standard may be higher ${ }^{77}$ than is medically necessary. ${ }^{78}$ Yet, if practitioners fall below the "high tech" medical standard they may be exposing themselves to liability. It would therefore be possible to provide "adequate" medical care that falls below the legal standard of care, as defined by medical custom. ${ }^{79}$ This problem is exacerbated by the emphasis that the courts place on medical treatments deemed in hindsight to be appropriate for a particular individual in a given situation and not on the "outcome measures" of the success of these procedures generally.

[A] provider who seeks to ration medical resources - for example, by ordering fewer or less costly tests, by providing a smaller margin of safety in terms of facilities or equipment availability, or by allowing less highly credentialed persons to perform certain procedures - runs the risk of increased exposure to malpractice liability in case of a medical maloccurrence. ${ }^{80}$

Therefore, even though a "low tech" medical procedure may have appeared to be appropriate and adequate at the time it was used, the fact that a "medical maloccurrence" subsequently develops may serve to characterize that procedure as substandard. ${ }^{81}$ In total, if a cost containment program was implemented requiring the use of less than "up-to-date" technology, it is likely that it would be the physician who would be held accountable. ${ }^{82}$

JAMA 505. See note 4 for a discussion of concerns regarding the efficacy of many medical procedures. See note 62.

It is important to note that by "higher standard of care" this article is generally not referring to the care, attention, and expertise which a physician must bring to her/his practice. Rather, it refers to the resources which the physician is expected to use. However, one could argue that in cost containment circumstances a physician may also need to "skimp" on his/her time thereby affecting the "care" provided.

A study by Langley et al., supra note 32, demonstrated that physicians clinical decisions are effected by a number of non-medical factors such as patient wishes, family wishes and medical legal factors. This study lends support to the concept that the standard of care (which is generally a reflection of the medical custom) may not always relate to medical necessity.

"Cost Containment", supra note 5 at 1733.

Blumstein, supra note 59 at 1395.

See W. Feldman, "To Test or Not to Test: A Medicolegal Problem" (April 1986) Leg. Aspects Med. Pract. 6 at 6, who appears to agree with Blumstein noting that "hindsight always wins over foresight."

In general see D. Roy et al., "The choice of contrast medium: medical, ethical and legal considerations" (1990) 147 CMAJ 1321 at 1323, for a discussion of legal and ethical implications of the use of high and low osmolar contrast media. In addition, the authors note at 1323: "medical and ethical limitations on the use of costly health care technologies cannot be sustained if the legal definition of standard medical practice is based on the illusion of unlimited resources." Also see "Stratified Scarcity", supra note 36 at 357, where it is noted that in the United States courts have shown little concern for the cost of the technology. See also LaFleur v. Cornelis, supra note 71. See also Picard, supra note 50 at 170 , where she notes that "a doctor electing the older method will have his conduct carefully scrutinized by the courts." 
Admittedly, the courts have always been sympathetic to the plight of physicians working with inadequate equipment and medical resources. ${ }^{83}$ This tendency is reflected in the judicial statements of the medical standard of care which traditionally calls for a consideration of the circumstances in which the alleged negligence has occurred. $^{84}$ As a result, the courts may adjust the standard downward to correspond with the inadequacy of equipment. ${ }^{85}$ Nevertheless, it is submitted that this judicial discretion would only be applied in circumstances where the equipment was inadequate due to circumstances beyond the clinical decision making power and control of the physician in question.

The fact that cost containment pressures result from resource allocation "choices" is an important aspect of the cost containment issue. It could be argued that an aggressive cost containment program would not be unique since most Canadian physicians have had to deal with situations requiring rationing at some time during their career. For example, rationing occurs when a physician makes determinations about the allocation of the limited number of Intensive Care Unit beds. ${ }^{86}$ Physicians practicing in rural settings are often forced to make clinical decisions with respect to medical resources that their urban counterparts may seldom experience. Medical practice during wartime also requires the profession to deal with an inadequate supply of health resources. These situations are, however, easily distinguished from cost containment programs because in the latter case, a physician may be asked to refrain from providing a given treatment even though it might actually be available. For example, physicians may be required to use a cheaper drug even though a more expensive drug, which may be marginally better, is available. During wartime, or in rural settings, circumstances and immediate necessity dictate the rationing process - not a government or hospital allocation policy.

Supporting this proposition is the fact that if a physician is required to choose a facility, he/she must do so with the best interests of his/her patient in mind. ${ }^{87}$ One wonders how a court would deal with an action where the physician chose a facility, or some form of equipment, for the purpose of economic efficiency.

\section{Discussion}

The above discussion is not meant to suggest that the present medical standard of care is too high. On the contrary, one of the greatest dangers of the cost containment

Picard, ibid. at 168. For a case law example of a court allowing less than optimum conditions to exist as a result of resource limitations see Bateman v. Doiron (1991), 8 C.C.L.T. 284 (N.B.Q.B.) aff' (1993), (188/91/CA) (N.B.C.A.). In that case the court held that a hospital would not be liable for staffing an emergency room with general practitioners if that is all that is available. However, as has been noted, a court may have difficulty coming to a similar conclusion in circumstances where the resource is limited as a result of a cost containment policy, rather than by an actual scarcity.

s. For example McCormick v. Marcotte, supra note 61.

ss $\quad$ Picard, supra note 50 at 169.

so Linton, supra note 15 at 8.

87 Kangas v. Parker, [1976] 5 W.W.R. 25, affd [1978] 5 W.W.R. 667 (Sask. C.A.). 
initiative is that it will allow the deterioration of the legal standard. The point is as follows: because of the circumstances and context which gave rise to the legal standard of care, it may be possible for a patient/plaintiff to demonstrate that his/her physician practiced below the current standard of care as a result of cost containment initiatives. This may be true even if, from the physician's perspective, it was believed that at the time of treatment the selected treatment was adequate. The issue then becomes whether a court will allow a reduction in the standard of care as a result of the cost containment constraints under which a physician may be practicing. This will be addressed in the next section of this article.

\section{LEGAL PRINCIPLES WHICH MAY ACCOMMODATE COST CONTAINMENT IN HEALTH CARE}

If one accepts that cost containment pressure may have the result of either explicitly or implicitly pressuring physicians to alter their practice patterns in a manner that is potentially below the current standard of care, then we must ask ourselves whether the tort system is flexible enough to accommodate this change in behaviour and, if it is, whether such an accommodation is desirable. This section will examine a number of the existing legal concepts which may be capable of responding to cost containment issues and which would thereby inhibit a patient/plaintiff's chances of successfully mounting a cost containment action. ${ }^{88}$

\section{The "Locality Rule"}

One legal doctrine that may be raised as a defence when a cost containment practice is implicated in a patient/plaintiff's injury is the "locality rule". Basically, this rule states that the standard against which a physician is to be judged is that of a reasonably prudent practitioner "in good standing in the community in the same line of practice." ${ }^{89}$ In Canada, judicial acceptance and application of the doctrine has varied over the years. ${ }^{90}$ While the rule seems to "refuse to die", ${ }^{91}$ its present impact on the outcome of Canadian decisions does not appear to be significant. ${ }^{92}$ Cases that do refer

A cost containment negligence action would still be a relatively unusual phenomena and the courts have a great capacity to avoid issues that they are not prepared to deal with. The courts may wish to discourage rationing-based malpractice actions due to the fear that they would further increase the cost of health care. Kapp argues that this judicial desire to avoid the creation of another malpractice avenue may be the most significant deterrent to increased negligence claims. He states as follows:

Thus the mechanisms of the legal system itself, quite apart from the merits of any specific claim, may serve as the most powerful brake on the use of malpractice litigation to enforce standards of quality of care in the wake of economically motivated rationing (supra note 40 at 458 ).

Meagher et al., supra note 50 at 39.

G. Robertson, "Doctrinal Developments in Canadian Health Care Liability, 1975-87" in Prichard, ibid. 26 at 26 [hereinafter "Doctrinal Developments"].

L. Klar, "Recent Developments in Canadian Law: Tort Law" (1985) 17 Ottawa L. Rev. 325 at 344. See ibid. at 344; Picard, supra note 50 at 177-178; "Doctrinal Developments", supra note 90 at 26-27; and "Law of Medical Liability", supra note 51 at 175. See also McCormick v. Marcotte, supra note 61 at 21, where Abbott J. of the Supreme Court of Canada stated that: "The medicine 
to a version of the rule are applying a standard of practice of practitioners in similar communities. ${ }^{93}$ However, in these cases the doctrine appears to have little bearing on the decision of the court. ${ }^{94}$

Nevertheless, because the jurisprudence supporting the locality rule is not dead, it may still be available for an attempted application in a cost containment claim. Furthermore, as the funding for health care decreases, the discrepancy between what is available in rural settings and what is available in urban settings may intensify. This is because many of the new technological advances are so costly that governments will likely limit their distribution to major health care institutions (e.g. MRIs). Over time this may create a dramatic difference between urban and rural medical care, thereby awakening the controversy over the locality rule.

The underpinnings that accompany the locality rule would lend themselves well to the defence of an allegedly negligent cost-conscious physician. In such a case, one would be asking the court to adjust the standard of care having regard to the economic pressures present (i.e. an "economic locality rule"). Indeed, the variation between the resources available to physicians practicing in different localities was one of the justifications for the development of the rule. ${ }^{95}$ Expanding the rule beyond geographic limitations to incorporate economic constraints would arguably be a logical extension. In fact, a number of commentators have considered the application of this doctrine as one legal mechanism which could deal with cost containment in health care. For example, Hall has concluded that the locality rule, which is still applied in approximately half of the United States, may be sufficient to absorb any legal developments generated by cost containment. ${ }^{96}$

While an increased application of this doctrine may be a tempting response to cost containment actions, it is submitted that the same criticisms which applied to the geographic rule would apply equally, or more, to an "economic locality rule". Firstly, plaintiffs would be unfairly limited in the expert witnesses they could call upon to

man must possess and use that reasonable degree of learning and skill ordinarily possessed by practitioners in similar communities in similar cases." It is this concept of "similar communities" that has kept the locality rule alive. However, in that same case the court went on to hold that since the defendant physician was within "easy reach of the largest centres of population" that he did not meet the standard of care. Arguably this has restricted the applicability of the rule substantially. See B. Chapman, "Controlling the Costs of Medical Malpractice: An Argument for Strict Hospital Liability" (1990) 28 Osgoode Hall L.J. 521 at 569, where he notes that the $M c$ Cormick decision has undermined the locality rule to a great degree.

Example McBride v. Langtons (1982), 22 Alta L.R.(2d) 174 at 184-85 (Alta Q.B.); Layden v. Cope (1984), 52 A.R. 70 (Alta Q.B.); Stewart v. Ross (1988), 64 Sask. R. 271 at 274 (Sask. Q.B.). Klar, supra note 91 at 344; and "Law of Medical Liability", supra note 51 at 175. See Haughian v. Paine (1986), 46 Sask. R. 186 at 190-91 (Sask Q.B.), (1987), 37 D.L.R. (4th) 624 (Sask C.A.), as an example of a situation where the court made reference to the locality rule and then applied it in a limited fashion. Walker J. stated as follows: "the locality rule is merely one circumstance and is not an absolute limit on the care and skill required. The standard of care and skill which is ordinarily employed by the profession generally is still [at] the heart."

"Cost Containment", supra note 5 at 1729.

M. Hall, "The Malpractice Standard under Health Care Cost Containment" (1989) 17 L. Med \& Health Care 347 at 349-50. 
testify. ${ }^{97}$ Finding a physician who practices under the same economic conditions as a defendant physician would undoubtedly be an onerous task. ${ }^{98}$ Secondly, allowing the use of a lower standard of care creates an environment where inferior health care may be deemed to be adequate. It would create a double standard such that patients whose physicians practice in communities which have fewer economic resources would, in effect, have restricted access to the courts, thereby limiting their recourse for inferior health care. ${ }^{99}$ Regardless, given the lack of impact that the locality rule has had on the standard of care in geographic situations, it seems unlikely that Canadian courts would overlook these problems and apply an economic locality rule.

Even if, for some reason, this type of legal doctrine was accepted in Canada, it would face another obstacle. Cost containment decisions are based on choice and not necessarily on the actual scarcity of a given resource. As a result, the application of the locality rule would require an expansion of the rule beyond mere circumstance to include conscious decisions by physicians to be more economically efficient. Morreim has taken note of this difficulty, stating as follows:

[W]e would have to expand the locality rule to cover both the unavailability of resources and conscious decisions to refrain from using available resources. Here the physician forgoes an intervention not because it cannot be procured or because the patient would not benefit, but because of a priority decision that this patient's benefit would not be certain enough or substantial enough to justify depriving other, needier patients. Such a stretching of the locality concept would not be a reasonable extension of its original meaning. ${ }^{100}$

In total, it is submitted that the locality rule would, and should, have little likelihood of succeeding as a defence to a malpractice action generated by a cost containment decision.

\section{2. "Accepted Practice" and "Respected Minority"}

Two of the most basic defenses to malpractice actions are that the acts of the defendant physician were either within the "accepted practice" or a "respected minority" of the profession. ${ }^{101}$ Will cost containment policies simply cause the medical norms to readjust, thereby lowering the standard of care and opening up the use, and effectiveness, of these defenses? ${ }^{102}$

Picard, supra note 50 at 177-78; "Criteria for Physician Standard of Care", supra note 21 at 11. At the present time in Canada, a plaintiff is not restricted to experts familiar with the standard in the defendant's community. "Doctrinal Developments", supra note 90 at 27.

See Picard, supra note 50 at 177 for a discussion of the impact of the geographic locality rule. See also Miller, supra note 31 at 69 , where he notes that an economic locality rule may extend protection to physicians when a potentially beneficial treatment is economically inaccessible to a underinsured patient.

"Cost Containment", supra note 5 at 1730 [emphasis in original].

Picard, supra note 50 at 231.

Kapp, supra note 40 at $\mathbf{4 6 0}$. 
In order to examine this issue more closely, we will focus on the "respected minority" doctrine since it is the defence which is most likely to initially be used. (This is because it can more easily adjust to subtle changes in the prevailing medical custom.) Further, most of the criticisms which apply to the "respected minority" apply equally to the "accepted practice" defence.

One of the primary difficulties with the "respected minority" defence, in the context of cost containment, is that it is only applicable when the defendant physician has "adhered to a distinct and respectable body of academic opinion." ${ }^{103}$ It is not enough for an expert witness to state that he/she, and a group of others, probably "would have done the same." ${ }^{104}$ As a result, a defendant must produce cogent evidence that his/her actions conform with an academic opinion. It may be difficult to find a medical "academic opinion" that embraces economic forces. ${ }^{105}$ Further, one could argue that this concept of academic opinion was meant to apply only to expert medical opinions (as opposed to an opinion regarding economic efficiency). Therefore, in a cost containment situation, all an expert physician witness could testify to is that he/she would have "done the same" since he/she could not provide medical reasons for the treatment decision in question. ${ }^{106}$

Another issue is whether a court would allow a reduction in the quality of care to be transformed into the legal standard of care. One of the rationales for having the respected minority doctrine is to promote the "advancement" of medical science - not to help its retreat. ${ }^{107}$ For it to apply to cost containment, the doctrine would have to be extended such that courts would accept a reduction in the quality of health care. ${ }^{108}$ While the courts' use of medical custom has allowed physicians to set their own standards, one could argue that this may only be done if they "uphold the existing quality of basic care."109 In reference to the courts' allowance for a deviation from the medical custom, Morreim stated as follows:

All of these allowances are predicated upon the principle that the interests of the patient are paramount. Where courts allow deviations from custom, they generally insist that the deviation improve, or at least preserve, the basic level of care. While they might allow physicians to eliminate literally useless customs and thereby avert needless iatrogenic injuries, courts are quite unlikely to endorse a cutback

J. Irvine, "Annotation" (1985) 32 C.C.L.T. at 159-60.

lbid.

Supra note 40 at $459-60$, where Kapp notes that medical norms presently do not embrace cost considerations. See also Brian v. Mador (1985), 32 C.C.L.T. 157 (Ont. C.A.).

It should be noted that it could be argued that a physician is not qualified as an expert on economic matters. Therefore, he/she could not provide an opinion in that area.

See Picard, supra note 50 at 233; and A. Linden, Canadian Tort Law (Toronto: Butterworths, 1988) at 34.

"Cost Containment", supra note 5 at 1736.

Ibid. at 1735 . 
that actually reduces the quality of the patient's care in order to benefit, not the patient, but the economic interests of some third party. ${ }^{110}$

Shuck made a similar observation in relation to the rationing of health care. $\mathrm{He}$ stated as follows:

Thus, not merely do professional norms tend to eschew rationing, but when a court musters the hubris to criticize a professional norm, it is plus royalistic que le roi - even more anti-rationing than the doctors. In short, if rationing is desirable, it is probably fatuous to expect courts in malpractice cases to legitimate it without the benefit of a statute. ${ }^{11 !}$

The court is not bound by the prevailing medical custom, or respected minority, presented by expert witnesses at trial. ${ }^{112}$ Further, case law indicates that courts recognize a duty to ensure a proper level of quality is maintained. In cases generated by cost containment programs this discretion may be used to find liability despite a profession-wide acceptance of a resource allocation policy. As was stated by Callahan J. in Hajgato v. London Health Assn.:

I do not accept, however, that the Court has no active role in determining the outcome in such matters. I accept that the evidence of approved practice is most helpful and persuasive and I fully recognize an absence of expertise in medical matters on the part of the Court. In my view, however, a court has a right to strike down substandard approved practice when common sense dictates such a result. No profession is above the law and the courts on behalf of the public have a critical role to play in monitoring and precipitating changes where required in professional standards. ${ }^{113}$

This supports the contention, as suggested by Morreim, that the courts may not be inclined to reduce the standard of care. Further, it may be argued that they have an obligation to maintain the higher standard despite evidence of accepted practice, or the views of a respected minority, to the contrary.

See ibid. at 1732-33 [footnotes omitted]. For case law examples, see Henderson v. Johnson, supra note 52 at 533-34, where it is noted that the fiduciary relationship which exists between physician and patient might dictate that the physician do what is in the best interest of the patient. See also Kangas v. Park, supra note 87, where it was held that the selection of a facility must be based on the best interest of the patient. See also Airedale NHS Trust v. Bland, [1993] H.L.J. No. 49, Law/Net at 7.

III P. Shuck, "Malpractice Liability and Rationing of Care" (1981) 59 Tex. L. Rev. 1421 at 1421.

112 See Anderson, supra note 62.

I13 (1982), 36 O.R. (2d) 669 at $692-93$ (H.C.), aff d (1983) 44 O.R. (2d) 264 at 693. See also United Blood Services v. Quintana, 827 P.2d 509 (Colo., 1992), where the Court stated the following in reference to an explicit national standard:

If the standard adopted by a practicing profession were to be deemed conclusive proof of due care, the profession itself would be permitted to set the measure of its own legal liability, even though that measure might be far below a level of care readily attainable through the adoption of practices and procedures substantially more effective in protecting others against harm than the self-decreed standard of the profession.

Thus, even nationally adopted "professional standards" or guidelines would likely only be used as evidence of the legal standard of care. See also Klar, supra note 91 at 225-28, for a general discussion of the legal significance of statutory "standards". 
There is a danger that, if public expenditure cuts lead to a decline in care, then the standards demanded by law will fall as doctors begin to work under a more limited regime. This downward boot strapping should be the subject of the courts' vigilance for neglect of duty does not cease by repetition to be neglect of duty. 114

A third difficulty, which may affect efforts to lower the standard of care in response to economic pressure, is the concept of "individual versus statistical" lives. ${ }^{115}$ Even though the idea of cost containment may be desirable on a societal level, courts deal with malpractice cases based on the claims of individuals who have been injured or are dead. Judges and juries may be quite sympathetic to individual plaintiffs ${ }^{116}$ and as a result may have difficulty imposing a utilitarian concept like economic restraint. ${ }^{117}$ Further, courts may have difficulty rejecting the patients' claims if it would require them to sanction a deviation from the traditional role of physicians - i.e. to do what is in the best interest of the patient. ${ }^{18}$

An example of the difficulty the American judiciary has in imposing economic considerations on individual patients is the case of Helling v. Carey. ${ }^{119}$ In this decision, the Court rejected all expert testimony concerning the necessary frequency of testing for glaucoma in the case of the particular plaintiff. As a result, it imposed liability. Commenting on this case, Milner noted that:

...the holding shows how easy [sic] one can lose sight of the need for cost containment when the tragedy of a single case is investigated. ${ }^{120}$

Not all commentators believe that the above-mentioned difficulties would prevent a downward trend in the standard of care. ${ }^{121}$ For example, Hall has suggested that the American courts will accept an adjustment to the medical standard of care. He argues that since courts reexamine the standard of care every time for each particular case "it will not easily detect a reduction in quality" and therefore will have no reason to object to its reduction. ${ }^{122}$ However, while it is true that courts deal with cases separately, a reduction in the standard of care would still require an acceptance of a standard lower than that presented by the plaintiff's experts (and they would undoubtedly put forward

R. Lee, "Doctors as Allocators - The Bald Facts" in S. McVeigh \& S. Wheeler, eds., Law, Health and Medical Regulation (Brookfield: Dartmouth Publishing Company Ltd, 1992) at 186.

Harvard, supra note 5 at 10.

See Hall, supra note 96 at 350 .

See Linton, supra note 15 at 8.

For example, see Stilling, supra note 6 at 301, where the author notes that the American Medical Association "believes that the beneficence principle must override any cost considerations at the level of physician-patient interactions." See also The Canadian Medical Code of Ethics, supra note 27.

Helling v. Carey, 519 P.2d 981 (1972).

"Criteria for Physician Standard of Care", supra note 21 at 3.

For example, see R. Rosenblatt, "Rationing Normal Health Care: The Hidden Legal Issues" (1981) 59 Tex. L. Rev. 1401 at 1418, who noted that "[m]alpractice law could - at least in theory accommodate a substantial amount of health care rationing because the law is largely within the control of the medical profession...."

Hall, supra note 96 at 349. 
evidence of the highest accepted standards). ${ }^{123}$ Therefore, a rationale for the lower standard would need to be explored by the court, thereby forcing the economic issue to the forefront.

Another reason a court may accept a lowering of the standard of care is the deference which is shown by the judiciary to the medical profession. ${ }^{124}$ As has been pointed out a number of times, courts rarely second-guess physicians and they are loath to impose "too rigorous a standard of care." ${ }^{125}$ The court's protective nature is further manifested in the very development of concepts like the "respected minority" which plays a uniquely significant role in malpractice cases. Nevertheless, while courts rarely interfere with the opinion of a qualified expert physician, when they do so it is generally to impose a higher standard. ${ }^{126}$ As a result, the court may not be as passive in their dealings with cost containment cases.

In summary, adjusting the standard of care through legal doctrines such as "respected minority" or "accepted practice" may be one of the more realistic, and likely, ways in which the tort system could accommodate the impact of cost containment. However, it is submitted that the need to address the issues discussed above will, at the very least, stall this judicial adjustment process. In particular, courts may have a difficult time accepting economic considerations as part of a "respected minority" position. Therefore, these defenses may not, at least initially, stand in the way of a patients' claim against physicians who, as a result of cost containment pressure, practice below the current legal standard of care.

\section{Economic Circumstance as an Excuse for Substandard Care}

The defences reviewed thus far are all based on the premise that the defendant physician would be denying the plaintiff's claim that he/she acted negligently (i.e. that he/she breached the standard of care). There are those who have suggested that a more affirmative defence may be appropriate for cost containment situations. ${ }^{127}$ To apply such a defence, a physician would admit that the treatment was substandard; however, he/she would then argue that he/she should be "excused" due to mitigating economic circumstances. This differs from the application of doctrines like the "locality rule" and "respected minority" in that the standard of care is not adjusted; rather an excuse is provided as to why substandard care was utilized. ${ }^{128}$

One could argue that if there was a completely uniform lowering of the standard of care then even the plaintiffs' experts would espouse the lower standard of care. However, such a quick and complete change in medical custom seems unlikely.

"Law of Medical Liability", supra note 51 at 175.

Ibid.

Harvard, supra note 5 at 1018; and Feldman, supra note 81 at 6.

For example, see Kapp, supra note 40 at 459.

See generally "Cost Containment", supra note 5; "Stratified Scarcity", supra note 36, for a discussion of the use of economic circumstance as an excuse for substandard care. Morreim suggests the use of a "rebuttable presumption" whereby the presumption that all physicians owe the same standard of care can be rebutted by evidence of economic restraint.

An economic excuse could be provided by legislation. See R. Nelson \& T. Drought, "Justice and the Moral Acceptability of Rationing Medical Care: The Oregon Experiment" 17 J. Med. \& Phil. 
An "economic excuse" would be a novel defence and at present it is doubtful that a court could accept such a claim without a significant jurisprudential evolution. ${ }^{129}$ Therefore, the arguments in favour of such a defence should be persuasive. Nevertheless, many commentators have suggested that there is a need for courts to begin recognizing the economic pressures faced by physicians. ${ }^{130}$

The adoption of a doctrine such as an "economic excuse" may appear to be a logical mechanism for dealing with the cost containment issue. A court could simply invoke the doctrine whenever it was satisfied that economic constraints were a factor in a given claim, thereby avoiding the need for a general lowering of the standard of care. While this may help to dissipate the negligence pressure physicians face, it is submitted that the concept has a number of problems which would make its implementation unwise and impractical.

First, as with the doctrines of "accepted practice" and "respected minority", the courts would be faced with the problem of trying to impose a social policy on an injured individual seeking compensation. As has been noted earlier, some commentators have questioned whether a court would accept an "economic excuse" when an individual has been hurt. ${ }^{131}$ In addition, by applying this doctrine one could argue that the courts would be taking an active role in facilitating the rationing of health care resources. Some believe this is not a role courts would feel comfortable assuming. ${ }^{132}$

A second problem which would flow from the adoption of an "economic excuse" is the complexity of evidence that would be required to present a defence. ${ }^{133} \mathrm{~A}$ defendant would need to document the economic circumstances present at the time the substandard care occurred and establish that they were such as to justify the quality of care provided. Undoubtedly, this would require a detailed analysis of the relevant health care region's economic climate in order to demonstrate that the physician in question was truly economically constrained. ${ }^{134}$ A plaintiff, in turn, would have to provide evidence to show that there were ample resources available and, therefore, that the substandard care should not be excused. In total, this would likely be a lengthy and complicated defence which would add to the already complex issues dealt with in most

97 at 106, where it is noted that the Oregon Act, Senate Bill 27, provides immunity to physicians from "criminal prosecution, civil liability or disciplinary action" if the physician refuses to provide an unfunded service. For example, a physician would be protected under the Oregon plan for the decision to forgo the use of a treatment which was not on the priority list.

See Kapp, supra note 40 at 459 , who suggests that in America economic excuse is not yet accepted as a defence. See also Kryworuk et al., supra note 45 at 11-12. For example, see Roy et al., supra note 82 at 1323 . See also "Cost Containment", supra note 5 at 1762 .

131 See Linton, supra note 15 at 8; Harvard, supra note 5 at 1018; and Hall, supra note 96 at 350. For example, see Shuck, supra note 111 at 1421; and generally, "Cost Containment", supra note 5; and C. Newdick, "Rights to NHS Resources After the 1990 Act" (1993) Med. L. Rev. 53 at 55. See generally Hall's criticism of Morreim's "rebuttable presumption", supra note 96. forth. 
malpractice actions. ${ }^{135}$ Further, as with the locality rule, a plaintiff may have difficulty finding effective experts with a knowledge of the economic circumstances involved, thereby making it unfairly difficult for a plaintiff to establish her or his case. ${ }^{136}$

A final criticism of the "economic excuse" involves the same policy considerations which apply to adjusting the standard of care. For example, the introduction of "costbenefit considerations into malpractice law could pervert the "caring" ideal in health care. ${ }^{1137}$ Further, like the lowering of the standard of care, this solution would place the burden of the problem on the shoulders of the patient and add another barrier to tort compensation.

In total, it is unlikely that a Canadian court would adopt this approach without some form of legislative intervention.

\section{DISCUSSION}

It seems inevitable that cost containment initiatives will cause the quality of health care to fall below that which is currently available. This, in turn, may result in an increase in patient injury which could cause patients to commence actions against their physicians. Whether these actions will be successful will depend on how the courts apply doctrines such as the "locality rule" and the "respected minority". It is submitted that there is sufficient grounds to assume that, at least initially, these defences may not be successful.

\section{THIRD PARTY LIABILITY - HOSPITALS AND THIRD PARTY DECISION-MAKERS}

While physicians will likely be principle targets of cost containment actions, other entities may also face increased liability exposure. Indeed, institutions such as hospitals will undoubtedly be called upon to make the practical resource allocation decisions, and therefore, they are arguably the more logical targets of these types of actions.

This section will start with a brief review of negligence law as it relates to hospitals. It will go on to look at the specific issue of how a third party, such as a hospital utilization review committee, may be held liable for its resource allocation decisions.

\section{A. HOSPITAL LIABILITY}

Hospitals across Canada are experiencing increased cost containment pressure as a result of a reduction in their global budgets. This may, and has, forced hospitals to implement a variety of cost-cutting measures. Due to this situation, hospitals and other

135 See "Criteria for Physician Standard Care", supra note 21, which argues for the increased use of expert witnesses in cost containment situations.

136 See Picard, supra note 50 at 177-78; and ibid. at 10, regarding the locality rule.

137 Harvard, supra note 5 at 1019. 
health care institutions may also be faced with an increase in malpractice exposure as a result of cost containment decisions at the "macro" (i.e. government) level. ${ }^{138}$

At the present time, hospitals can be found liable on the basis of direct or vicarious liability. ${ }^{139}$ An institution can be found directly negligent if it breaches one of the legal duties it owes the patient (e.g. to select competent staff, to provide proper instruction and supervision, to provide proper facilities and equipment and to establish systems necessary for the safe operation of the hospital). ${ }^{140}$ While there has been a broadening of the scope of these duties, ${ }^{141}$ and therefore increased findings of direct liability, hospital malpractice exposure is still relatively limited. For example, in the leading case of Yepremian v. Scarborough General Hospital, ${ }^{142}$ the Court failed to expand the legal duties of hospitals to include the duty of providing patients with a reasonable standard of treatment.

A hospital can also be found vicariously liable for the negligent actions of its employees. ${ }^{143}$ The effect of this doctrine is to impose liability on the employer hospital for the torts of its employees committed within the scope of their employment. ${ }^{144}$ In Canada, courts have continued to hold that physicians are independent contractors, and therefore, no vicarious liability can be imposed on the hospital for physicians' negligent actions. ${ }^{145}$

As noted earlier in this article (see note 16), a tension presently exists between physicians and hospitals which would arguably make the implementation of cost containment programs difficult. (See generally Chapman, supra note 92; Iglehart, supra note 16; and Harvard, supra note 5 at 1013-17 for a discussion of the hospital/physician conflict). The need to reduce this tension makes hospitals a logical target for legal reform. Generally, this conflict relates to the incentives which encourage physicians to over-utilize the system (e.g. defensive medicine, patient and professional expectations and fee-for-service compensation) and the pressure on hospitals to contain costs. Harvard, ibid. at 1022, expressed this conflict as follows: "Cost containment initiatives subject hospitals to incentives that conflict with those that current malpractice law create for physicians." This conflict is heightened by the present distribution of liability among physicians and hospitals such that physicians would bear most of the increased malpractice exposure which may be associated with cost containment programs. As Harvard succinctly summarized the issue:

If we are to maintain high standards of care while lowering medical costs, current malpractice law should be modified to bring these conflicting incentives into alignment. In addition, fairness requires that the malpractice burden be bome by hospitals as well as physicians, because of their shared responsibility for medical mishaps that result from cost-cutting measures (ibid.).

Another reason they are a logical target for reform is the fact that 80 percent of all malpractice flows from hospitals (Chapman, supra note 92 at 539; Evans, supra note 73; and Dewees \& Trebilcock, supra note 74 at 86 , where it was noted that 90 percent of all "large" claims occur in hospital settings).

See generally Picard, supra note 50 at 299-327.

"Law of Medical Liability", supra note 51 at 181-82; and Chapman, supra note 92 at 527.

"Law of Medical Liability", ibid. at 182.

142 (1980), 110 D.L.R. (3d) 513 (Ont. C.A.) [hereinafter Yepremian]. It is interesting to note that the Supreme Court of Canada has not yet had the issues raised in this case before it. 
In total, hospitals have been relatively insulated from malpractice exposure by the operation of the independent contractor doctrine and the limited application of direct institutional liability. Nevertheless, from a cost containment perspective, hospitals may be faced with liability exposure if economic circumstances force them to breach their standard of care. For example, a hospital may be held liable if it fails to have adequate equipment or drugs available $e^{146}$ or fails to provide adequate staff. ${ }^{147}$ Clearly, then, if the quality of hospital services decreases, liability will become a potential dilemma. As with physicians, the issue that then arises is whether economic constraint will be permitted as a defense.

A number of British decisions, where patient/plaintiffs sued health authorities for poor hospital conditions, may have somewhat stifled the effectiveness of this defense. In Bull v. Devon Health Authority, for instance, an infant plaintiff suffered brain damage as a result of the breakdown in the defendant's system for providing emergency obstetric care. The Health Authority's defence that they did the best they could given the limited resources was rejected by the Court:

It is not necessarily an answer to allegations of unsafety that there were insufficient resources to enable the administrators to do everything which they would like to do. ${ }^{148}$

In general, it seems that hospitals face the same predicament as the physicians; if the quality of care slips below the current standard of care, then liability exposure will increase. And, as with physicians, pointing to the operation of a resource allocation policy will not necessarily be a successful defence.

\section{B. LIABILITY OF THIRD PARTY DECISION MAKERS}

In addition to the general scarcity of resources that may result as hospitals see their budgets decrease, and thereby result in the liability exposure referred to above, hospitals, and other third party decision makers, will likely be called upon to help make actual resource allocation decisions. This section will examine how this decision making responsibility may also lead to tort liability.

While provincial governments control the total global budgets of hospitals, the way in which health care is delivered "is determined by the hospital board, its

For example see Lahey v. Craig (1992), 92 I.L.R. 499 (N.B.Q.B.).

Jinks v. Cardwell (1987), 39 C.C.L.T. 168 (H.C.). In this case the hospital was found liable for not having enough nurses on staff. However, in the case of Bateman v. Doiron, supra note 92, the Court held that a hospital was not negligent for staffing its emergency room with general practitioners since that was all that was available. See also Kryworuk et al., supra note 45 at 21-22.

Bull v. Devon Health Authority (1989) 1 Lancet 738 (C.A.) and HIV Haemophiliac Litigation (1990) 140 N.L.J. 1349; Newdick, supra note 132. See also Knight v. Home Office, [1990] 3 All E.R. 237 at 243; Wilsher v. Essex H.A., [1987] Q.B. 730 at 778 [hereinafter Knight]. In Knight, the Court noted that "[i]t is not a complete defence for a government department ... to say that no funds are available for additional safety measures." However, the court did lower the standard of care having regard to the resources available. 
administration, and its professional staff." 149 As a result, a large number of the cost containment decisions and policies will be formulated by hospitals. Can hospitals, and other third party decision makers, be held liable for these decisions even if the physician is the ultimate allocator of the resource?

The California case of Wickline v. The State dealt with this issue. ${ }^{150}$ In that case the Court took the relatively radical step of suggesting that, in certain circumstances, the entities who formulate the cost containment programs (e.g. utilization review committees) can be held legally accountable for their decisions. ${ }^{151}$ While some feel this is a logical evolution in malpractice jurisprudence, ${ }^{152}$ it nevertheless represents one of the most explicit judicial responses to cost containment. Further, it serves as an illustration of how courts may adapt tort law to accommodate economic restraint in health care.

The facts of the Wickline case are straight forward. ${ }^{153}$ Ms. Wickline was admitted to the hospital for treatment due to a blockage of her abdominal aorta caused by arteriosclerosis. Medi-Cal, which was paying for the treatment, authorized surgical treatment and ten days of hospital time. ${ }^{154}$ After the initial surgery, complications arose and two additional operations were required. Ms. Wickline's physician determined that an additional eight days hospitalization was necessary. He submitted the requisite Medi-Cal forms; however, the medical consultants for the government insurer partially rejected the request by only authorizing four additional hospital days. Ms. Wickline's physician made no formal complaint regarding Medi-Cal's decision and she was discharged after the four extra hospital days. Subsequently, her leg lost circulation and her physician had to amputate above the knee.

As a result of the injury, Ms. Wickline sued the State of California for "negligently discontinu[ing her] Medi-Cal eligibility, causing [her] to be discharged prematurely and whil [sic] in need of continuing hospital care." 15s While the jury award of $\$ 500,000$ was overturned on appeal, ${ }^{156}$ the Court made it clear that a third party decision maker could be held liable for an allocation decision:

Brown, supra note 14 at 114 .

Wickline, supra note 38.

Ibid. at 670.

For example, Morreim states as follows: "The responsibility we could once simplistically ascribe to physicians is anachronistic in the face of the complex responsibilities engendered by the increasingly complex economics of health care." E. Morreim, "Whodunit? Causal Responsibility of Utilization Review for Physicians' Decisions, Patients' Outcomes" (1992) 20 L. Med \& Health Care 40 at 42-43 [hereinafter "Whodunit?"].

Wickline, supra note 38 at 663-69. See also Lairson, supra note 25 at 791-800; Stilling, supra note 27 at 288-91; and Sederer, supra note 6 at 1157-58, for a general review of the case.

See Stilling, ibid. at 289.

Wickline, supra note 38 at 662.

The Court held that even though Ms. Wickline was released four days earlier than originally recommended, this was not below the medical custom, and therefore, it was not negligent. See ibid. at 669-71: 
The patient who requires treatment and who is harmed when care which should have been provided is not provided should recover for the injuries suffered from all those responsible for the deprivation of such care, including, when appropriate, health care payors. Third party payors of health care services can be held legally accountable when medically inappropriate decisions result from defects in the design or implementation of cost containment mechanisms as, for example, when appeals made on a patient's behalf for medical or hospital care are arbitrarily ignored or unreasonably disregarded or overridden. $^{157}$

As has already been stated, the Wickline decision has generally been considered an example of how third party decision makers may be held liable for their cost containment programs and policies. ${ }^{158}$ However, it should be emphasized that in this case the utilization review committee imposed economic pressure which only may have influenced a medical decision. ${ }^{159}$ The utilization review committee merely came to the conclusion that it would no longer pay for further hospital days. It did not have the power to actually ration the hospital beds. Despite this relatively indirect influence, the court still seemed willing to impose liability on the third party. This is important for several reasons. First, it is judicial recognition that decisions about funding for medical treatments may attract the same liability as actual medical decisions. This is probably an accurate reflection of reality since for patients with limited economic resources a funding decision is a medical decision.

Second, it is recognition that mere economic pressure by third parties can influence physicians' medical decisions to the point of amounting to negligence. Obviously, if a resource is explicitly rationed by a third party decision maker then a physician may have no control over its utilization. In such a situation, a redistribution of liability is logical. However, the Wickline decision suggests that such explicit rationing may not be necessary to influence physicians' clinical decision making process. In other words, economic pressure may be enough to force physicians to do other than that which would normally be clinically indicated ${ }^{160}$ and, as such, this pressure may be enough to attract liability. Therefore, a third party decision maker, such as a hospital utilization review committee, could be held liable when "medically inappropriate decisions result from defects in the design or implementation" of a cost containment program ${ }^{161}$ even if it did not have direct control over the physician involved. ${ }^{162}$

Ibid. at 671; see also "Whodunit?", supra note 152 at 41.

For example, see generally Sederer, supra note 6.

See Wickline, supra note 38 at 671.

See generally William \& Beresford, supra note 6, where it is noted that this is already occurring. Wickline, supra note 38 at 671.

There have been a number of other American decisions which have dealt with this issue. For example, Wilson v. Blue Cross of Southern California, 271 Cal. Rptr. 876 (Cal. App. Dist., 1990) and Corcoran v. United Health Care Insurance, 965 Fed. Rptr. (2d) 1321, (5th Cir. Court, 1992). In the latter case, the Court suggested that these types of claims are useful as they represent "an important check on the thousands of medical decisions routinely made in the burgeoning utilisation review system." at 1338. In a discussion of the duty of health authorities to patients the issues of proximity and foresight was addressed by Newdick, supra note 132 at 66 :

There is a strong argument that the requirements of foresight and proximity are satisfied so as to create a duty on the part of the service to organise its system in a way that is reasonably capable of responding to those in circumstances of 
A number of British decisions support the premise that a third party decision maker could be held liable for the negligent "design or implementation" of a cost containment scheme. In Wilsher v. Essex H.A., the Court stated:

Although we were told in argument that no case has ever been decided on this ground and that it is not the practice to formulate claims in this way, I can see no reason why, in principle, the health authority should not be so liable if its organisation is at fault. ${ }^{163} 1$

\section{Newdick commented:}

Wilsher and Bull suggest that, given the proximity between hospitals and patients, inadequate management systems will not be permitted to excuse negligent treatment, which ought to be governed exclusively by the medical standard of care. ${ }^{164}$

While to date there have been no Canadian decisions directly on point, ${ }^{165}$ there is presently an ongoing case in British Columbia which utilizes similar concepts as those in Wickline. ${ }^{166}$ That case arises as a result of the death of an individual who was on the waiting list for cardiac surgery. The statement of claim names the Minister of Health as a defendant and alleges that he breached his duty to the deceased by "failing to provide accessible hospital services to the Deceased, pursuant to the Canada Health Act and the Hospital Insurance Act." ${ }^{167}$ In addition, the plaintiff is also suing the hospital for inter alia: "Failing to establish an adequate system of priorities for the admission of patients when the facilities for treatment of these patients were overburdened, or, in the alternative, failing to utilize an adequate system." ${ }^{168}$

emergency who depend on it.

[1987] Q.B. 730 at 778. See also Bull, supra note 148. A number of British public law cases have suggested that resource allocation policy decisions by government authorities will not be interfered with by the courts, see Newdick, ibid. at 54-56. However, in negligence actions the courts have been more sympathetic to the plaintiffs' claims.

Newdick, ibid. at 60 . See also J. Tingle, "The Allocation of Healthcare Resources in the National Health Service in England: Professional and Legal Issues" (1993) 2 Ann. Health L. 195 at 210:

The judge's statements reveal definite attitudes about healthcare resource accountability and responsibility. The judge appears to imply that hospital under-resourcing by the government will not result in judicial acceptance of a reduced standard of patient treatment...

There have been other Canadian "resource allocation" cases against the government, however, these have been cases based on the Canadian Charter of Rights and Freedoms, Part I of the Constitution Act, 1982, being Schedule B to the Canada Act 1982 (U.K.), 1982, c. 11 [hereinafter Charter]. For example see Brown v. British Columbia (Minister of Health) (1990), 66 D.L.R. (4th) 444 (B.C.S.C.). In that case the plaintiff brought an action against the government for failing to fund AZT therapy for AIDS patients. See also Ontario Nursing Home Association v. Ontario (1990), 44 O.R. (2d) 365 , where the plaintiff unsuccessfully argued that the funding for nursing homes violated sections 7 and 15 of the Charter, and Jasmin c. Cite de la Sante de Laval, [1990] R.J.Q. 502 (C.S.) as discussed in M. Rivet, "Allocation and Rationing of Health Resources: Patients' Challenges to Decision-Making" (1993) Health Care Eth. \& L. 17. 
This claim is quite consistent with the liability concepts presented in Wickline. Since there have been no Canadian decisions directly on point, it is difficult to predict the outcome of this case; however, at the very least, it demonstrates that the Canadian health care system is not immune to the introduction of these types of actions. ${ }^{169}$

\section{NEW AREAS OF LIABILITY}

Cost containment in health care may also impose new legal duties on physicians. For instance, it has been suggested that physicians will have to adopt the role of "economic advocate". ${ }^{170}$ This new duty would place an obligation on physicians to do their best to obtain access to scarce, and/or rationed, resources for their patients. If the requirements imposed by this duty are not satisfied, then a physician could be held liable for any treatment which falls below the judicially accepted standard of care. In addition, a patients may have an action against his/her physician based on a breach of fiduciary duty.

\section{A. THE CONCEPT OF "ECONOMIC ADVOCATE"}

The general concept of the physician as an advocate of the patient's interests is obviously not new. ${ }^{71}$ It is a duty which flows from the fiduciary nature of the physician/patient relationship. Further, physicians have always been responsible for procuring access to medical resources for their patients. This was noted by Naylor as follows:

The physician's role in the health care system is pivotal as far as the use of resources is concerned.

Because of the wide gap in information between doctor and patient and the emotional connotations of serious illness, doctors are expected to serve both as suppliers of services and as purchasing agents on their patients' behalf for services such as hospital days, drugs, diagnostic tests and consultations with other physicians. ${ }^{172}$

However, as economic resources become increasingly scarce, physicians may be required to solicit actively for priority of access to medical resources on behalf of their patients over other physicians' patients. To some degree this may already be occurring. For example, waiting lists for cardiac surgery are generally determined after an analysis

This may be an area where legislation is suggested. For example, in Yepremian, supra note 142 at 545 , the court stated as follows:

If liability is to be imposed upon hospitals for the negligence of its medical staff, including specialists, not employed by the hospitals, whether directly or by imposing a statutory duty to provide such services, it should be the function of the Legislature, as a policy question, to decide whether and under what conditions such liability is to attach.

It is submitted that a patient/plaintiff would be more successful imposing liability on a third party by framing the action as a separate negligent act beyond medical malpractice (e.g. the negligent "design or implementation" of a cost containment program). and Stilling, supra note 27. 
of each patients' medical needs. In Great Britain patients see their physicians as advocates fighting for their share of that country's scarce medical resources. ${ }^{173}$ Nevertheless, in Canada, the role of the physician as an advocate has never been explicitly stated as a legal duty.

It could be argued, however, that physicians already have this duty by virtue of their legal obligations to treat their patients. ${ }^{174}$ In this respect it would not be a development outside the realm of malpractice law, but merely an extension of the duties and obligations which physicians already owe. ${ }^{175}$

The physician may very well be the best person to fill the role of economic advocate. For instance, a physician is probably the only person who could effectively present the medical reasons why a given resource is necessary for his/her patient. Stilling, an American commentator, noted that:

\begin{abstract}
A physician who possesses cultural authority to define appropriate therapy is the person in the best position to make appeals on behalf of the patient. Not only does the patient lack knowledge about his or her medical condition, the patient probably understands little about the nuances of insurance coverage. This is especially true because patients are in a vulnerable condition. ${ }^{176}$
\end{abstract}

This statement is probably equally true in Canada despite the existence of publicly funded universal health care coverage (i.e. Canadian patients do not have to deal with insurance companies).

To a large extent the concept of "economic advocacy" is a result of the controversial Wickline decision discussed above. In that case, the Court held that a third party decision maker could only be held liable if the physician had done his/her best to secure the needed resource. ${ }^{177}$ The Court stated that:

[T]he physician who complies without protest with the limitations imposed by a third party payer, when his medical judgment dictates otherwise, cannot avoid his ultimate responsibility for his patient's care. $^{178}$

See R. Lee \& F. Miller, "The Doctor's Changing Role in Allocating United States and British Medical Services" (1990) $18 \mathrm{~L}$. Med \& Health Care 69 at 74.

174 See Lairson, supra note 25 at 808. "Economic advocacy" may also form part of the physician's fiduciary duty to the patient.

i7s Ibid. at 118n., where she notes that in America "[i]t is not a new duty, but merely a logical expansion of the duty of continued care. In this context, a physician who acts unreasonably would be liable for abandonment or for a lack of due diligence."

176. Stilling, supra note 27 at $298-99$.

17 It should be noted that "medical resource" can take many forms. For example, in the Wickline, supra note 38, case the resource was the funding for hospital days.

17w Ibid. at 670-71. See also Stilling, supra note 6 at 297 where the author argues that the language of the decision "reinforces the physician's duty to consider patients' health needs first and financial considerations second." 
There have been no similar decisions in Canada; ${ }^{179}$ however, as noted above, this duty would merely be an extension of the duties already owed to the patient by the physician. As a result, it may be within the power of the judiciary to decide that this is a legal duty without the need for legislative intervention.

Morreim is one author who is a strong proponent of the development of an "economic advocate" duty. ${ }^{180}$ In fact, she believes that physicians should have two additional duties in a world of cost containment. First, physicians should act as economic advisors, explaining both medical and economic options to their patients. ${ }^{181}$ For example, a physician should explain all the options that would be medically beneficial and what resources he/she could provide without an additional charge to the patient. In addition, the physician should advise the patient about the differences between the "free" and "extra-cost" items and whether or not it would be advisable, given the patient's medical and financial circumstances, for the patient to expend the extra money. This would become particularly relevant if provinces choose to adopt some form of user fee or co-payment system.

Second, the physician would have the duty to act as his/her patient's "economic advocate". Under this duty, physicians would need to take reasonable steps to procure access to all the medical resources that they feel are necessary for the benefit of their patients. This may encompass an obligation to protest a "funding decision" made by a third party payor. Morreim believes that one of the important aspects of this duty is that it embraces the idea that physicians do not fully control health care resources and that third party decision makers play a large part in the decision making process. ${ }^{182}$

\section{B. ACTIONS BASED ON A BREACH OF THE FIDUCIARY DUTY}

While the primary focus of this article is on the principles of tort liability, it should be noted that it may also be possible to bring an action against a physician who withholds treatment as a result of cost containment pressure, based on the breach of the

179 However, see Sallis, supra note 22, a Canadian case which has yet to go to trial.

180 See "Stratified Scarcity", supra note 36 at 360-62. Also, the American Medical Association has stated that it agrees with the concept of the physician as the patient's advocate; see Stilling, supra note 27 at 301 .

131 This may form part of an expanded informed consent doctrine obligation.

182 See "Stratified Scarcity", supra note 36 at 361 . This raises the issue of whether a physician has the same obligations to all patients regardless of the patient's financial circumstances. Must a physician advocate a patient's economic needs to a third party if the patient could clearly pay for the needed treatment from his/her own financial resources? By forcing a third party payor to finance a wealthy patient's treatment, resources for less affluent patients, who may be in greater medical need, may become more scarce. On the other hand, it would probably be reasonable to insist that physicians use the same "standard of advocacy" for all patients without regard to the patients' economic circumstances. Otherwise, it could be argued that there is a two-tiered medical care system - one in which the physician only acts as an economic advocate for persons who are in financial need. 
fiduciary duty. ${ }^{183}$ Given the recent Supreme Court decisions of McInerney v. MacDonald and Norberg v. Wynrib, which reemphasized the fiduciary nature of the physician/patient relationship, a physician may be held legally accountable for a breach of any of the duties which flow from this "trust" relationship. ${ }^{184}$ Arguably, one of these duties includes the obligation to do whatever is in the best interest of the patient. ${ }^{185}$ Therefore, continuing to treat a patient during the existence of a conflict of interest, such as third party pressure to practice efficiently, may amount to a breach of the fiduciary duty, particularly if this conflict has not been disclosed to the patient. ${ }^{186}$

This legal duty places additional pressure on physicians to do what they are traditionally trained to do - place the interests of the patient first. ${ }^{187}$ As noted by B.M. Dickens: "[b]ehaviour that wasn't illegal but unethical may now become illegal as well." ${ }^{\text {mo }}$ Given the lack of medical-legal cases based on the fiduciary duty, it is difficult to predict how a court would react to such a claim. As noted above, claims generated by cost containment can clearly be framed in tort and, as such, a court may be more comfortable classifying the action in terms of negligence in order to avoid the introduction of a new mechanism for suing physicians. ${ }^{189}$

\section{CONCLUSION}

This article began by asking whether, in this era of cost containment, tort law could serve Canadian patients as an effective mechanism for protecting their access to high quality health care. In other words, could patients successfully sue physicians, or other health care providers and institutions, for injuries caused by the operation of cost containment policies?

On balance, it appears that tort law may be, at least in the short term, a viable mechanism for patients who wish to obtain compensation for injuries that result from

See J. Brooke, "Ruling on files leaves MDs open to lawsuits" (1993) 29 The Medical Post 58 at 58; and M. Christie, "Physician Liability for Treatment Decisions Influenced by Utilization Management" (1993) [Dalhousie Law School: Unpublished paper].

McInerney v. MacDonald, supra note 52; and Norberg v. Wynrib (1992), 92 D.L.R. (4th) 449 (S.C.C.). See also Henderson v. Johnston, supra note 52. See also Moore v. Regents of the University of Cal., 2119 Cal. Rptr. 494, (1988) rev'd, 793 P.2d 479 (Cal., 1990).

See "Whodunit?", supra note 152 at 42 , where the author argues that "physicians have a duty, as the patient's fiduciary, to ensure the patient receives care of a certain standard."

For example, see Kangas v. Parker, supra note 87, where the court held that a physician should not let treatment decisions be affected by financial gain.

See The Canadian Medical Code of Ethics, supra note 27; and American College of Physicians Ethics Manual, supra note 27 at 948 where it is stated that "[t]he patient's best interest must be the physician's main concern." See also The Council on Ethical and Judicial Affairs of the American Medical Association (1989) at 2.03 in Stilling, supra note 27 at 301, where it is suggested that the physician's duty is to place the patient's interest above of fiscal restraint. See also "Cost Containment", supra note 5 at 1727: "To permit physicians routinely to balance their patients' interest against other's economic welfare could devastate [the] fiduciary relationship."
In Brooke, supra note 183 at 58.

It is submitted that at the very least physicians' fiduciary duty creates an obligation to disclose to patients any conflict that may be present as a result of cost containment pressure. 
health care that is substandard due to the operation of cost containment initiatives. ${ }^{190}$ Moreover, other avenues of compensation may surface as a result of the economic restructuring in health care thereby bolstering patients' legal options (e.g. increased third party liability in the nature of the Wickline decision and actions based on a breach of the duty to act as the patient's economic advocate). ${ }^{191}$ In fact, a number of authors have argued that legal actions flowing from resource allocation decisions should be encouraged. ${ }^{192}$ They view the court as an important agent in the process of quality control. ${ }^{193}$ While the ability of the courts, and the tort system in general, to fill this role may be questionable, ${ }^{194}$ it does indicate that at least some stakeholders believe it is important for the Canadian judiciary to get involved in this increasingly complex issue. In addition, it emphasizes that the pressure to maintain a high quality of care should, and will, continue.

Whether tort law will remain an effective "weapon" in the patient's legal arsenal will depend on the tort systems ability to accommodate cost containment. Such accommodation would likely be manifested in an adjustment of the legal standard of care. However, we have seen that a number of the traditional legal defences used in malpractice actions, such as the locality rule and the respected minority, may not be effective against a cost containment malpractice action. Nevertheless, it seems inevitable that negligence law will eventually adjust to the realities of health economics.

However, given the time, cost and emotional energy needed to run a malpractice action, this may not be an attractive legal option for many injured patients.

19

The nature of the physicians informed consent obligation may also be affected by cost containment in health care.

192 For example, see Lairson, supra note 25 at 803; Rozovsky, supra note 22; and Sederer, supra note 6.

For example, Lairson, ibid. at 805-06 stated as follows: "By holding a physician liable when the patient's reimbursement method or amount is incorporated into the treatment decision, courts affirm the duty of care and help assure that care meets professionally recognized standards."

194 See Elgie et al., supra note 48 at 106-112. 